\title{
Synthesis, Crystallographic Structure, Hirshfeld Surface Analysis, Drug-likeness Properties and Molecular Docking Studies of New Oxime-pyridine Compounds
}

\author{
Tufan Topal ${ }^{\star}$ \\ Department of Chemistry, Pamukkale University, 20020, Denizli, Turkey, \\ * Corresponding author: E-mail: tufantopal@hotmail.com \\ Phone: +90 258 2963457, fax: +902582963535
}

Received: 06-11-2020

\begin{abstract}
A detailed description of the two new pyridine ligands, (2E,3Z)-3-[2-(3-chloropyridin-2-yl)hydrazinylidene]-N-hydroxybutan-2-imine and 3-chloro-2-\{(2Z)-2-[1-(4 nitrophenyl)ethylidene]hydrazinyl $\}$, is reported. The synthesized compounds were characterized by spectroscopic studies, spectral features were performed by TD-DFT calculations. New-generation pyridine ligand of $\mathrm{HL}_{2}$ was also determinate by single-crystal X-ray diffraction and Hirshfeld surface analysis with two-dimensional fingerprint plots was used to analyze intermolecular interactions in crystals. Molecular-docking was performed to investigate the binding areas of chemical compounds, and the results showed the inhibitory activity of the studied $\mathrm{HL}_{1}$ and $\mathrm{HL}_{2}$ against E. coli. The results of the current study revealed the drug-likeness and bioactive properties of the ligands.
\end{abstract}

Keywords: Pyridine-oxime; molecular electrostatic potential (MEP); Drug-likeness; E. Coli; Hirshfeld surface analysis; $\mathrm{X}$-ray diffraction

\section{Introduction}

For biological activities, pyridine compounds are widely used as antibacterial, antifungal, and anticancer agents. ${ }^{1-3}$ Several studies have been conducted on biological compounds in health-related journals and books. Accordingly, pyridine derivatives cause interactions with high binding capacity by targeting enzymes, proteins, and deoxyribonucleic acid (DNA) that create biological problems. ${ }^{4}$ With the discovery of new compounds, several studies were performed in the last decade to inhibit antibacterial drug resistance and reduce associated adverse effects on human health. ${ }^{5}$ It is clear that new types of viruses and bacteria affect the lives of humans worldwide in a variety of ways. Accordingly, this places immense responsibility on researchers and chemists who work to develop new materials to decrease the effects of viruses and bacteria as well as biologists and physicians who test the new compounds on animals and humans. Requiring extensive research, conducting in vitro studies is costly and time-consuming; accordingly, one of the most important advantages of the current study was the contribution to perform in silico studies inactivating viruses, bacteria, and cancer cells by the production of ligands with medicinal potential. Pyridine and oxime compounds have a high interference of hydrogen bond in electrostatic potential capacity. Intramolecular and intermolecular hydrogen bonds play a major role in the interacting and binding of biological molecules. In addition, pyridine and oxime compounds have been selected particularly for their ability to easily transfer the electrons of nitrogen atoms participating in the aromatic ring and $\mathrm{C}=\mathrm{N}$ groups into the donor-acceptor system. ${ }^{6-11}$ Due to their high levels of antibacterial properties and bioactive multizones, nitrogenous organic or inorganic compounds are reported to have positive effects on Escherichia coli. ${ }^{12}$ The reason for the investigation of E. coli pathogens in molecular-docking studies is this bacterium's resistance against some medications and its high binding capacity. ${ }^{5}$ Furthermore, E. coli, also known as the most-common human pathogen, causes different types of infections, such as kidney, gallbladder, skin, and respiratory infections in addition to meningitis in neonates. ${ }^{13,14}$ The physicochemical properties of compounds affect bioavailability, including electrostatic potential, molar absorptivity, stability, solubility, structure, intracellular absorption, hydrogen bonds, and bonding energy. ${ }^{15,16}$ The theoretical method such as Density Functional Theory (DFT) in the computational chemistry is 
important tool to predict the assignment of specific electronic transitions in the UV-Vis spectra. In the present study, oxime and pyridine derivative compounds were synthesized and characterized by X-ray and spectroscopic methods. In addition, the surface analysis was performed to analyze their chemical properties, and molecular electrostatic potential was calculated to determine the nucleophilic and electrophilic zones. Molecular-docking was conducted to investigate the hydrogen-binding interactions of $E$. coli DNA gyrase subunit $\mathrm{B}(\mathrm{GyrB})$ and $E$. coli beta-ketoacyl-acyl carrier protein synthase III (FabH) and determined pharmacokinetic and pharmacological properties.

\section{Materials and Methods}

\section{1. Materials and Physical Measurements}

The chemicals and solvents: methanol, acetonitrile, 3-chloro-2-hydrazinopyridine, 2,3 butanedione monoxime, $4^{\prime}$-nitroacetophenone were obtained from Sigma-Aldrich. BRUKER BIOSPIN NMR AVANCE Spectrometer III $400 \mathrm{MHz}$ model spectrometer was used for ${ }^{1} \mathrm{H}-\mathrm{NMR}$ and ${ }^{13} \mathrm{C}$-NMR analysis. Elemental analysis were determined using a Costech Elemental analysis device ECS 4010 Model analyzer. IR spectrums were recorded in the $400-4000 \mathrm{~cm}^{-1}$ on Perkin Elmer FTIR-Spectrometer Spectrum Two Model and Mass Spectra (ESI) on TSQ Fortis ${ }^{\mathrm{TM}}$ Triple Quadrupole Mass Spectrometer. Melting points of ligands were determined by Stuart SMP10. The mains water was passed through the Thermo Scientific Smart2pure device to make it pure water. Absorption spectra was carried out using Shimadzu UV-1800 UV-VIS spectrophotometer. Single-crystal X-ray structure was determined using an Agilent SuperNova Dual CCD detector diffractometer eguipped with graphite-monochromated MoKa radiation $\left(\lambda=0.71073^{\circ} \mathrm{A}\right)$ at room temperature.

\section{2. Synthesis of Ligands $H_{1}, H L_{2}$}

Chemical preparation of (2E,3Z)-3-[2-(3-chloropyridin-2-yl)hydrazinylidene]- $N$-hydroxybutan-2-imine $\mathrm{HL}_{1}$ and 3-chloro-2-\{(2Z)-2-[1-(4-nitrophenyl)ethylidene]hydrazinyl $\}$ pyridine $\mathrm{HL}_{2}$.

3-chloro-2-hydrazinopyridine ( $1 \mathrm{mmol}, 0.1435 \mathrm{~g}$ ) in acetonitrile solution $(10 \mathrm{ml})$ was added 2,3 butanedione monoxime ( $1 \mathrm{mmol}, 0.1011 \mathrm{~g}) \mathrm{HL}_{1}$ and $4{ }^{\prime}$-Nitroacetophenone $(1 \mathrm{mmol}, 0.1651 \mathrm{~g}) \mathrm{HL}_{2}$ in $10 \mathrm{ml}$ of acetonitrile respectively (Fig.1). The both solution stirred for $24 \mathrm{~h}$ at room temperature and were kept aside for slow evaporation of solvent for about 5 days. The $\mathrm{HL}_{2}$ crystal was obtained from slow evaporation technique by dissolving the product in acetonitrile.

$\mathrm{C}_{9} \mathrm{H}_{11} \mathrm{ClN}_{4} \mathrm{O}\left(\mathrm{HL}_{1}\right)$, Crem; Yield 87\%. m.p.: $194{ }^{\circ} \mathrm{C}$. ${ }^{1} \mathrm{H}-\mathrm{NMR}\left(400 \mathrm{MHz}\right.$, Chloroform-d $\left.\mathrm{d}_{6}, \mathrm{ppm}\right): \delta 9.83(\mathrm{~s}, 1 \mathrm{H}$, $\mathrm{O}-\mathrm{H}), \delta 8.45(\mathrm{~s}, 1 \mathrm{H},-\mathrm{NH}), \delta 8.37$ (d, $1 \mathrm{H}, \mathrm{Ar}-\mathrm{H}), \delta 7.62(\mathrm{~d}$, $1 \mathrm{H}, \mathrm{Ar}-\mathrm{H}), \delta 6.84(\mathrm{t}, 1 \mathrm{H}, \mathrm{Ar}-\mathrm{H}), \delta 2.34\left(\mathrm{~s}, 3 \mathrm{H},-\mathrm{CH}_{3}\right), \delta$ $2.23\left(\mathrm{~s}, 3 \mathrm{H},-\mathrm{CH}_{3}\right) .{ }^{13} \mathrm{C}-\mathrm{NMR}\left(100 \mathrm{MHz}\right.$, Chloroform- $\mathrm{d}_{6}$, ppm): $\delta 157.39(-\mathrm{C}=\mathrm{N}-\mathrm{OH}), \delta 157.32(-\mathrm{C}=\mathrm{N}-), \delta 150.00$, $147.12,137.32,116.50,115.35$ (C-Ar pyridine $), \delta 10.03$ $\left(-\mathrm{CH}_{3}\right), \delta 9.53\left(-\mathrm{CH}_{3}\right) .{ }^{17} \mathrm{LC} / \mathrm{MS}-\mathrm{MS}$, (ESI) $\mathrm{m} / \mathrm{z}=226.66284$ $[\mathrm{M}+1]^{+}(100 \%)$. Calcd. for $\mathrm{C}_{9} \mathrm{H}_{11} \mathrm{ClN}_{4} \mathrm{O}: \mathrm{C}, 47.69 ; \mathrm{H}, 4.89$; $\mathrm{N}, 24.72 \%$; found: C, 47.71; H, 4.86; N, 24.69\%. IR (KBr) $\mathrm{cm}^{-1}: 3357(\mathrm{~N}-\mathrm{H}), 3112(\mathrm{O}-\mathrm{H}), 2981\left(\mathrm{C}-\mathrm{H}_{\mathrm{Ar}}\right), 1596(\mathrm{C}=\mathrm{N})$ pyridine, $1561(\mathrm{C}=\mathrm{N})_{\text {imine }}, 1516(\mathrm{C}=\mathrm{N})_{\text {oxime }}, 935(\mathrm{~N}-\mathrm{O})$.

$\mathrm{C}_{13} \mathrm{H}_{11} \mathrm{ClN}_{4} \mathrm{O}_{2}\left(\mathrm{HL}_{2}\right)$, Orange; Yield 86\%. m.p.: $169^{\circ} \mathrm{C}$. ${ }^{1} \mathrm{H}-\mathrm{NMR}$ (400 MHz, Chloroform-d $\left.\mathrm{d}_{6}, \mathrm{ppm}\right): \delta 8.48(\mathrm{~s}, 1 \mathrm{H}$, -NH), $\delta 8.30(\mathrm{~d}, 1 \mathrm{H}, \mathrm{Ar}-\mathrm{H}), \delta 8.20(\mathrm{~d}, 2 \mathrm{H}, \mathrm{Ar}-\mathrm{H}), \delta 8.01(\mathrm{~d}$, $2 \mathrm{H}, \mathrm{Ar}-\mathrm{H}), \delta 7.61(\mathrm{~d}, 1 \mathrm{H}, \mathrm{Ar}-\mathrm{H}), 6.84(\mathrm{t}, 1 \mathrm{H}, \mathrm{Ar}-\mathrm{H}), \delta 2.38$ (s, $\left.3 \mathrm{H},-\mathrm{CH}_{3}\right),{ }^{13} \mathrm{C}-\mathrm{NMR}\left(100 \mathrm{MHz}\right.$, Chloroform- $\left.\mathrm{d}_{6}, \mathrm{ppm}\right)$ : $\delta$ 149.92, $\delta 147.61$ (C-Ar pyridine $), \delta 147.17(-\mathrm{C}=\mathrm{N}-), \delta$ $144.49,144.42$ (C-Ar), $\delta 137.33$ (C-Ar pyridine $), \delta 126.89$, $126.89,123.64,123.64(\mathrm{C}-\mathrm{Ar}), \delta 116.97,115.49$ (C-Ar ${ }_{\text {pyri- }}$ dine), $\delta 12.53\left(-\mathrm{CH}_{3}\right)$. LC/MS-MS, (ESI) $\mathrm{m} / \mathrm{z}=290.70558$

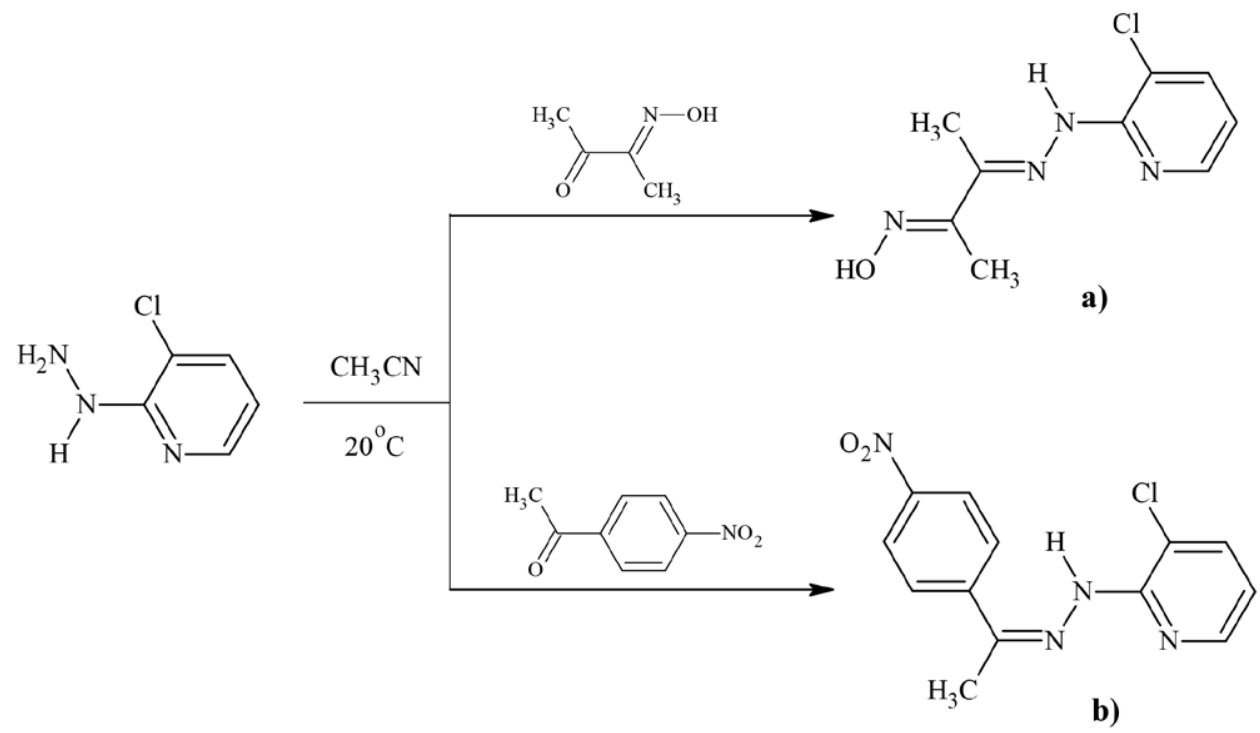

Fig. 1. Structure of compounds a) $\mathrm{HL}_{1}$ and b) $\mathrm{HL}_{2}$ 
$[\mathrm{M}+1]^{+}(100 \%)$. Calcd. for $\mathrm{C}_{13} \mathrm{H}_{11} \mathrm{ClN}_{4} \mathrm{O}_{2}: \mathrm{C}, 53.71 ; \mathrm{H}$, 3.81 ; N, 19.27\%; found: C, 53.73; H, 3.79; N, 19.22\%. IR $(\mathrm{KBr}) \mathrm{cm}^{-1}: 3378(\mathrm{~N}-\mathrm{H}), 2922\left(\mathrm{C}-\mathrm{H}_{\mathrm{Ar}}\right), 1585(\mathrm{C}=\mathrm{N})_{\text {pyridine }}$, $1557(\mathrm{C}=\mathrm{N})_{\text {imine }}, 1392\left(\mathrm{NO}_{2}\right) \cdot{ }^{18} 1 \mathrm{H} \mathrm{NMR}$ and $\mathrm{UV}-\mathrm{Vis}$ spectra. Reaction of 1:1 stoichiometric proportion of $\mathrm{HL}$ with $\mathrm{Na} 2[\mathrm{PdCl} 4]$ in methanol affords a mononuclear palladium(II

\section{3. X-ray Crystallography Analysis}

Orange crystal of the $\mathrm{C}_{13} \mathrm{H}_{11} \mathrm{ClN}_{4} \mathrm{O}_{2}$ compound was obtained in acetonitrile solution through slow evaporation for 5 days at room temperature. The data set of reflections were collected using an Agilent SuperNova X-Ray diffractometer with $\mathrm{MoKa}(\lambda=0.71073)$ at $293 \mathrm{~K}$. The data reduction and data correction were performed by Olex 2 software (version 1.3). ${ }^{19,20}$ Refinements were obtained by the Full-Matrix method on $\mathrm{F}^{2}$ using the Olex2 software, and crystal packing diagrams were created by Mercury 4.3.0 software. All the nonhydrogen atoms were anisotropically refined using the riding model approximation. ${ }^{21}$ Tables 1 and 2, a summary of the experimental details of $\mathrm{HL}_{2} \cdot{ }^{22-24}$ CCDC DOI: 10.5517/ccdc.csd.cc24rlzh and number 1988897 contains the supplementary rystallographic data for this work. This data can be obtained from The Cambridge Crystallographic Data Centre via www.ccdc.cam.ac.uk/data_request/cif.

\section{Results and Discussion \\ 3. 1. Description of the Crystal Structures and Hydrogen Bonding}

Slow evaporation technique was used to make the sample suitable for X-ray structure analysis. The $\mathrm{HL}_{2}$ crys-
Table 1. Crystal data and structure refinement for $\mathrm{HL}_{2}$.

\begin{tabular}{|c|c|}
\hline CCDC number & 1988897 \\
\hline Empirical formula & $\mathrm{C}_{13} \mathrm{H}_{11} \mathrm{ClN}_{4} \mathrm{O}_{2}$ \\
\hline Formula weight & 290.71 \\
\hline Temperature/K & 293(2) \\
\hline Crystal system & monoclinic \\
\hline Space group & $\mathrm{P} 2{ }_{1} / \mathrm{c}$ \\
\hline $\mathrm{a} / \AA$ & $11.7767(7)$ \\
\hline $\mathrm{b} / \AA ̊$ & $14.4529(7)$ \\
\hline$c / \AA$ & $7.9073(4)$ \\
\hline$\alpha /^{\circ}$ & 90 \\
\hline$\beta /^{\circ}$ & $91.381(5)$ \\
\hline$\gamma / /^{\circ}$ & 90 \\
\hline Volume $/ \AA^{3}$ & $1345.49(12)$ \\
\hline $\mathrm{Z}$ & 4 \\
\hline$\rho_{\text {calc }} \mathrm{g} / \mathrm{cm}^{3}$ & 1.435 \\
\hline$\mu / \mathrm{mm}^{1}$ & 0.291 \\
\hline $\mathrm{F}(000)$ & 600.0 \\
\hline Crystal size $/ \mathrm{mm}^{3}$ & $0.14 \times 0.13 \times 0.12$ \\
\hline Radiation & Mo Ka $(\lambda=0.71073)$ \\
\hline $2 \Theta$ range for data collection $/^{\circ}$ & 6.756 to 49.996 \\
\hline Index ranges & $\begin{array}{l}-8 \leq \mathrm{h} \leq 14,-16 \leq \mathrm{k} \leq 16 \\
-8 \leq \mathrm{l} \leq 9\end{array}$ \\
\hline Reflections collected & 4286 \\
\hline Independent reflections & $\begin{array}{l}2343\left[\mathrm{R}_{\text {int }}=0.0161\right. \\
\left.\mathrm{R}_{\text {sigma }}=0.0302\right]\end{array}$ \\
\hline Data/restraints/parameters & $2343 / 0 / 182$ \\
\hline Goodness-of-fit on $\mathrm{F}^{2}$ & 1.047 \\
\hline Final $\mathrm{R}$ indexes $[\mathrm{I}>=2 \sigma(\mathrm{I})]$ & $\mathrm{R}_{1}=0.0548, \mathrm{wR}_{2}=0.1338$ \\
\hline Final R indexes [all data] & $\mathrm{R}_{1}=0.0790, \mathrm{wR}_{2}=0.1491$ \\
\hline Largest diff. peak/hole / e $\AA^{-3}$ & $0.21 /-0.41$ \\
\hline
\end{tabular}

tallizes in the centrosymmetric space group $\mathrm{P} 22_{1} / \mathrm{c}$ of monoclinic system with a unit cell volume of 1345.49 (12) $\AA^{3}$, the cell dimensions are: $\mathrm{a}=11.7767(7) \AA$, $\mathrm{b}=14.4529(7)$

Table 2. Selected Bond Lengths $/ \AA ̊$, Angles $/{ }^{\circ}$ and Torsion $/{ }^{\circ}$ for $\mathrm{HL}_{2}$.

\begin{tabular}{|c|c|c|c|c|c|c|c|c|c|c|c|}
\hline Atom & Atom & Length & Atom & Atom & Atom & Angle & Atom & Atom & Atom & Atom & Torsion \\
\hline N7 & N8 & $1.355(3)$ & C9 & N8 & N7 & $117.57(19)$ & N7 & N8 & C9 & $\mathrm{C} 10$ & $-1.6(3)$ \\
\hline N8 & C9 & $1.287(3)$ & N8 & N7 & $\mathrm{C} 2$ & $121.4(2)$ & N8 & N7 & $\mathrm{C} 2$ & N1 & $-1.4(4)$ \\
\hline N1 & $\mathrm{C} 2$ & $1.329(3)$ & $\mathrm{C} 2$ & N1 & C6 & $117.2(3)$ & $\mathrm{C} 2$ & N1 & C6 & H6 & $-179.5(4)$ \\
\hline N1 & C6 & $1.333(4)$ & $\mathrm{C} 13$ & $\mathrm{C} 12$ & C9 & $120.2(2)$ & C13 & $\mathrm{C} 12$ & C9 & N8 & $8.3(3)$ \\
\hline C9 & $\mathrm{C} 12$ & $1.474(3)$ & $\mathrm{C} 17$ & $\mathrm{C} 12$ & C9 & $122.1(2)$ & C9 & N8 & N7 & $\mathrm{H} 7$ & $-4.3(4)$ \\
\hline $\mathrm{C} 12$ & $\mathrm{C} 13$ & $1.397(3)$ & $\mathrm{C} 17$ & $\mathrm{C} 12$ & $\mathrm{C} 13$ & $117.7(2)$ & $\mathrm{C} 2$ & N7 & N8 & C9 & $175.7(2)$ \\
\hline $\mathrm{C} 12$ & $\mathrm{C} 17$ & $1.391(3)$ & N1 & $\mathrm{C} 2$ & $\mathrm{C} 3$ & $122.5(2)$ & C6 & N1 & $\mathrm{C} 2$ & N7 & $-177.6(3)$ \\
\hline $\mathrm{C} 3$ & $\mathrm{C} 2$ & $1.394(4)$ & $\mathrm{C} 4$ & $\mathrm{C} 3$ & $\mathrm{C} 2$ & $118.7(3)$ & C6 & N1 & $\mathrm{C} 2$ & C3 & $2.4(4)$ \\
\hline $\mathrm{C} 9$ & $\mathrm{C} 10$ & $1.505(3)$ & $\mathrm{C} 12$ & C9 & $\mathrm{C} 10$ & $120.8(2)$ & $\mathrm{C} 10$ & C9 & $\mathrm{C} 12$ & $\mathrm{C} 13$ & $-170.9(2)$ \\
\hline $\mathrm{C} 14$ & $\mathrm{C} 13$ & $1.375(3)$ & N8 & C9 & $\mathrm{C} 12$ & $115.0(2)$ & N8 & C9 & $\mathrm{C} 12$ & $\mathrm{C} 17$ & $-172.1(2)$ \\
\hline $\mathrm{C} 17$ & $\mathrm{C} 16$ & $1.369(4)$ & N8 & $\mathrm{C} 9$ & $\mathrm{C} 10$ & $124.2(2)$ & C10 & C9 & $\mathrm{C} 12$ & $\mathrm{C} 17$ & $8.7(3)$ \\
\hline $\mathrm{C} 15$ & C14 & $1.379(4)$ & N7 & $\mathrm{C} 2$ & $\mathrm{C} 3$ & $118.7(2)$ & N8 & C9 & $\mathrm{C} 10$ & $10 \mathrm{HA}$ & -55.3 \\
\hline $\mathrm{C} 4$ & $\mathrm{C} 3$ & $1.375(4)$ & C16 & $\mathrm{C} 17$ & $\mathrm{C} 12$ & $122.0(2)$ & N8 & C9 & $\mathrm{C} 10$ & $10 \mathrm{HB}$ & -175.3 \\
\hline C6 & C5 & $1.368(5)$ & N1 & $\mathrm{C} 2$ & N7 & $118.9(2)$ & N8 & C9 & $\mathrm{C} 10$ & $10 \mathrm{HC}$ & 64.7 \\
\hline C5 & $\mathrm{C} 4$ & $1.371(5)$ & N1 & C6 & C5 & $124.2(3)$ & $\mathrm{C} 12$ & C9 & $\mathrm{C} 10$ & $10 \mathrm{HA}$ & 123.9 \\
\hline N7 & $\mathrm{C} 2$ & $1.371(3)$ & $\mathrm{C} 14$ & C15 & N18 & 119.1(3) & $\mathrm{C} 12$ & C9 & $\mathrm{C} 10$ & $10 \mathrm{HB}$ & 3.9 \\
\hline $\mathrm{C} 16$ & C15 & $1.361(4)$ & C14 & $\mathrm{C} 13$ & $\mathrm{C} 12$ & $120.6(2)$ & $\mathrm{C} 12$ & C9 & $\mathrm{C} 10$ & $10 \mathrm{HC}$ & -116.1 \\
\hline
\end{tabular}


$\AA, c=7.9073(4) \AA, \beta=91.381(5)^{\circ}$ and $Z=4$. The full data collection was done for indices $h, k$ and $l$ with ranges of -8 $\leq \mathrm{h} \leq 14,-16 \leq \mathrm{k} \leq 16,-8 \leq 1 \leq 9$ and $\mathrm{R}$ value of $\mathrm{R}_{1}=0.0548$, $\mathrm{wR}_{2}=0.1338$. Carbon and hydrogen atoms have been geometrically positioned.

The bond lengths between the atoms N8=C9 1.287(3) Å, N7-N8 1.355(3) ̊, C9-C12 1.474(3) ̊̊, C12-C13 1.397(3) $\AA \AA$ and C12-C17 1.391(3) Å were found. In literature 1.28(14) $\AA, 1.35(3) \AA, 1.49(14) \AA, 1.39(15) \AA$ and $1.38(16) \AA$ are similar with our values of atomic lengths. ${ }^{25-27}$ The $\mathrm{N} 8=\mathrm{C} 9$ bond was shorter than the N8-N7 bond and it confirms that $\mathrm{N} 8=\mathrm{C} 9$ shows a double bond character. $\mathrm{In} \mathrm{HL}_{2}$, pyridyl N1$\mathrm{C} 2$ and N1-C6 bond distances were 1.329(3) and 1.333(4) $\AA$, bond angle $\mathrm{C} 2-\mathrm{N} 1-\mathrm{C} 6117.2(3)^{\circ}$ and torsion angle $\mathrm{C} 2$ $\mathrm{N} 1-\mathrm{C} 6-\mathrm{H} 6-179.5(4)^{\circ}$ were found and this torsion value is competible with the expected $180^{\circ} .{ }^{11,28}$ Torsion angles of atoms between pyridyl and benzene ring have been observed C13-C12-C9-N8 8.3(3) $)^{\circ}$ N8-N7-C2-N1 -1.4(4) ${ }^{\circ}$ and N7-N8-C9-C10 -1.6(3) ${ }^{\circ}$. The ORTEP-3 drawn with $35 \%$ probability is given in Fig. 2.

Basically 3 pairs of hydrogen bond interactions are observed in the structure, these are $\mathrm{C}-\mathrm{H} \cdots \mathrm{O}, \mathrm{C}-\mathrm{H} \cdots \mathrm{N}$ and $\mathrm{C}-\mathrm{H} \cdot \cdots \mathrm{Cl}$ intramolecular and intermolecular hydrogen bonds. ${ }^{29,30}$ Selected hydrogen bond distances and angles are listed in Table 3. In $\mathrm{HL}_{2}$, carbon atom C10 acts as a donor to $\mathrm{N} 1$ atom at $\mathrm{C}(10)-\mathrm{H}(10 \mathrm{~A}) \cdots \mathrm{N}(1)(\mathrm{x}, 1.5-\mathrm{y},-1 / 2+\mathrm{z})$,

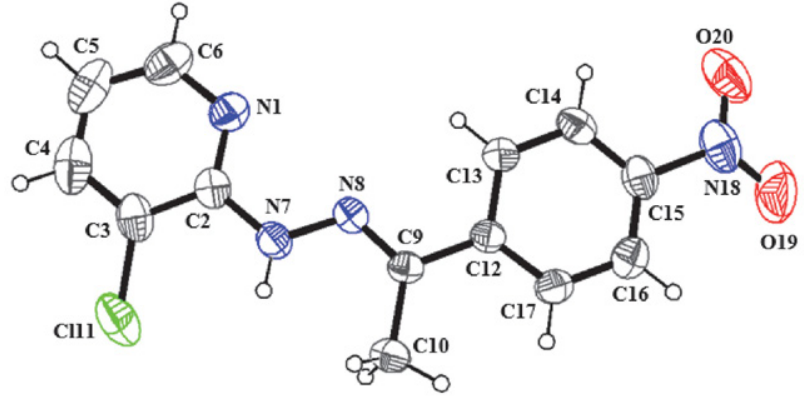

Fig. 2. Molecular structure of the $\mathrm{HL}_{2}$. Thermal ellipsoids are shown at $35 \%$ probability level

developing the capped stick style and two-dimensional chain along the crystallographic axis as depicted in Fig. 3a. As illustrated in Fig. 3b, in $\mathrm{HL}_{2}$, C-H...O intermolecular hydrogen bonding interactions were used to generate a three-dimensional (3D) supramolecular network along the $\mathrm{c}$ axis. All the figures were drawn in Mercury software. Other hidrogen bonds were $\mathrm{C}(10)-\mathrm{H}(10 \mathrm{~A}) \cdots \mathrm{Cl}(11)(1-\mathrm{x}, 2-$ $\mathrm{y}, 1-\mathrm{z}), \quad \mathrm{C}(5)-\mathrm{H}(5) \cdots \mathrm{O}(20) \quad(1-\mathrm{x}, 1-\mathrm{y}, 1-\mathrm{z}), \mathrm{C}(10)-\mathrm{H}(10 \mathrm{~B}) \cdots$ $\mathrm{O}(19)(2-\mathrm{x},-1 / 2+\mathrm{y}, 1 / 2-\mathrm{z}), \mathrm{C}(17)-\mathrm{H}(17) \cdots \mathrm{O}(20)(2-\mathrm{x},-1 / 2$ $+\mathrm{y}, 1 / 2-\mathrm{z}), \mathrm{C}(5)-\mathrm{H}(5) \cdots \mathrm{O}(19)(-1+\mathrm{x}, \mathrm{y}, 1+\mathrm{z}), \mathrm{C}(10)-$ $\mathrm{H}(10 \mathrm{~B}) \cdots \mathrm{O}(20)(2-\mathrm{x},-1 / 2+\mathrm{y}, 1 / 2-\mathrm{z}), \mathrm{C}(13)-\mathrm{H}(13) \cdots \mathrm{Cl}(11)$ $(1-\mathrm{x}, 2-\mathrm{y}, 1-\mathrm{z}){ }^{31}$

Table 3. Selected hydrogen bond distances $(\AA)$, symmetry and angles $\left(^{\circ}\right)$ for $\mathrm{HL}_{2}$.

\begin{tabular}{|c|c|c|c|c|c|}
\hline $\mathrm{D}-\mathrm{H} \cdots \AA$ & d (D-H) & $d(H \cdots \AA)$ & 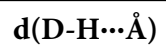 & Symmetry codes & $\angle \mathrm{D}-\mathrm{H} \cdots \AA$ \\
\hline $\mathrm{C}(10)-\mathrm{H}(10 \mathrm{~A}) \cdots \mathrm{Cl}(11)$ & 0.960 & 3.174 & 3.882 & $1-x, 2-y, 1-z$ & 131.90 \\
\hline $\mathrm{C}(10)-\mathrm{H}(10 \mathrm{~A}) \cdots \mathrm{N}(1)$ & 0.960 & 2.768 & 3.602 & $x, 1.5-y,-1 / 2+z$ & 145.68 \\
\hline $\mathrm{C}(5)-\mathrm{H}(5) \cdots \mathrm{O}(20)$ & 0.930 & 3.019 & 3.606 & $1-x, 1-y, 1-z$ & 122.57 \\
\hline $\mathrm{C}(10)-\mathrm{H}(10 \mathrm{~B}) \cdots \mathrm{O}(19)$ & 0.960 & 2.730 & 3.417 & $2-x,-1 / 2+y, 1 / 2-z$ & 129.08 \\
\hline $\mathrm{C}(17)-\mathrm{H}(17) \cdots \mathrm{O}(20)$ & 0.930 & 2.460 & 3.322 & $2-\mathrm{x},-1 / 2+\mathrm{y}, 1 / 2-\mathrm{z}$ & 154.19 \\
\hline $\mathrm{C}(13)-\mathrm{H}(13) \cdots \mathrm{Cl}(11)$ & 0.930 & 2.941 & 3.764 & $1-x,-1 / 2+y, 1.5-z$ & 148.37 \\
\hline $\mathrm{C}(5)-\mathrm{H}(5) \cdots \mathrm{O}(19)$ & 0.930 & 2.909 & 3.747 & $-1+\mathrm{x}, \mathrm{y}, 1+\mathrm{z}$ & 150.54 \\
\hline $\mathrm{C}(10)-\mathrm{H}(10 \mathrm{~B}) \cdots \mathrm{O}(20)$ & 0.960 & 3.057 & 3.978 & $2-x,-1 / 2+y, 1 / 2-z$ & 161.22 \\
\hline
\end{tabular}
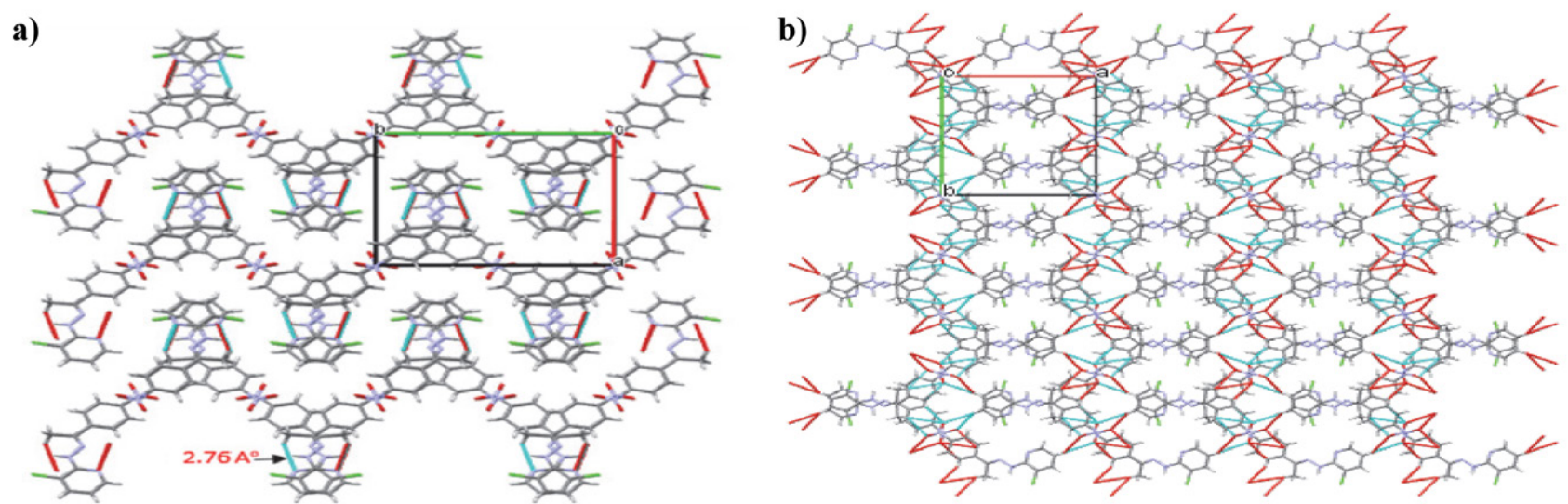

Fig. 3. a) Two-dimensional self-assembling; b) three-dimensional supramolecular frameworks of $\mathrm{C}_{13} \mathrm{H}_{11} \mathrm{ClN}_{4} \mathrm{O}_{2}$ and hydrogen bonds 


\section{2. ${ }^{1} \mathrm{H}$ NMR Studies}

${ }^{1} \mathrm{H}-\mathrm{NMR}$ spectrum of $\mathrm{HL}_{1}$ is shown in Fig. 4. ${ }^{1} \mathrm{H}$-NMR spectrum of the $\mathrm{HL}_{1}$ ligand oxime $(\mathrm{N}-\mathrm{OH})$ group of the proton (H13) was observed at $9.83 \mathrm{ppm}$ as a singlet peak. The $\mathrm{NH}$ proton $(\mathrm{H} 8)$ generated a signal at $8.45 \mathrm{ppm}$. The spectrum of the (2E,3Z)-3-[2-(3-chloropyridin-2-yl)hydrazinylidene]- $N$-hydroxybutan-2-imine ligand observed at singlet peaks $2.23 \mathrm{ppm}(\mathrm{H} 14 \mathrm{~A}, \mathrm{H} 14 \mathrm{~B}$, $\mathrm{H} 14 \mathrm{C})$ and $2.34 \mathrm{ppm}(\mathrm{H} 15 \mathrm{~A}, \mathrm{H} 15 \mathrm{~B}, \mathrm{H} 15 \mathrm{C})$ methylene group of protons. While $\mathrm{H} 1$ proton signal appeared at $\mathrm{d}$ $8.37 \mathrm{ppm}$, the signals at $\mathrm{d} 7.62$ and $\mathrm{d} 6.84 \mathrm{ppm}$ were due to $\mathrm{H} 3$ and $\mathrm{H} 2$ of pyridinium moiety, respectively. ${ }^{32} \mathrm{In} \mathrm{HL}_{2}$, the $\mathrm{NH}$ proton (H7) generated a sharp signal at $8.48 \mathrm{ppm}$, as a singlet peak. The peaks were observed at range 8.30$6.84 \mathrm{ppm}$ were assignable to the protons of aromatic rings as multiplet peaks. The spectrum of the 3-chloro-2-\{(2Z)2-[1-(4-nitrophenyl)ethylidene]hydrazinyl\}pyridine ligand observed at singlet peaks $2.38 \mathrm{ppm}(\mathrm{H} 10 \mathrm{~A}, \mathrm{H} 10 \mathrm{~B}$, $\mathrm{H} 10 \mathrm{C})$ methylene group of protons. The signal at $\mathrm{d} 8.30$ ppm was attributed at to (H6) aromatic proton of pyridine. The proton signal appearing at $\mathrm{d} 8.20$ and $\mathrm{d} 8.01 \mathrm{ppm}$ were due to $(\mathrm{H} 13, \mathrm{H} 17, \mathrm{H} 16, \mathrm{H} 14)$ of aromatic moiety respectively. Aromatic protons of pyridine moiety produced a broad signal at d 7.61 and t $6.84 \mathrm{ppm}(\mathrm{H} 5, \mathrm{H} 4) .{ }^{11,18,33} \mathrm{It}$ was observed that the obtained results were exactly compatible with the structure.

\section{3. ${ }^{13} \mathrm{C}$ NMR Studies}

${ }^{13} \mathrm{C}$-NMR spectrum of $\mathrm{HL}_{1}$ is shown in Fig. 5. ${ }^{13} \mathrm{C}$-NMR spectrum $\mathrm{HL}_{1}$ observed a single resonance at 157.39 and $157.32 \mathrm{ppm}$, respectively which showed that the oxime $(\mathrm{C}=\mathrm{NOH})$ and hydrazone $(-\mathrm{NHN}=\mathrm{CH})(\mathrm{C} 11, \mathrm{C} 10)$ carbon atoms. All the signals were assigned to the aromatic carbons (C1-C5) of the pyridine at the range of 150.00$115.35 \mathrm{ppm}$. The signals observed at 10.03 and $9.53 \mathrm{ppm}$ are attributable to the carbon atom of methyl group $(\mathrm{C} 15, \mathrm{C} 14)$. For $\mathrm{HL}_{2}$, aromatic carbons of pyridine and benzene rings gave different signals in their resonance. Hence the signals at $149.92,147.61,137.33,116.97,115.49 \mathrm{ppm}$ were due to carbon (C2-C6) while (C12-C17) presented in different signals at $144.49,144.42,126.89,126.89,123.64$, $123.64 \mathrm{ppm}$ in the aromatic moiety of ligand. Two equivalent para carbons $(\mathrm{C} 13, \mathrm{C} 17)$ and $(\mathrm{C} 14, \mathrm{C} 16)$ brought out a signals at $\mathrm{d} 126.89$ and $123.64 \mathrm{ppm}$ in the spectrum. The signal at $147.17 \mathrm{ppm}$ was due to the (C9) carbon of the imine group of moiety. The signal observed at $12.53 \mathrm{ppm}$ is attributable to the carbon atom of methyl group (C10). ${ }^{25,32,33}$

\section{4. UV-Vis Absorption Spectra and TD-DFT Calculations}

UV-Vis calculations were performed by TD-DFT/ B3LYP method with 6-31G basis set using Gaussian 09

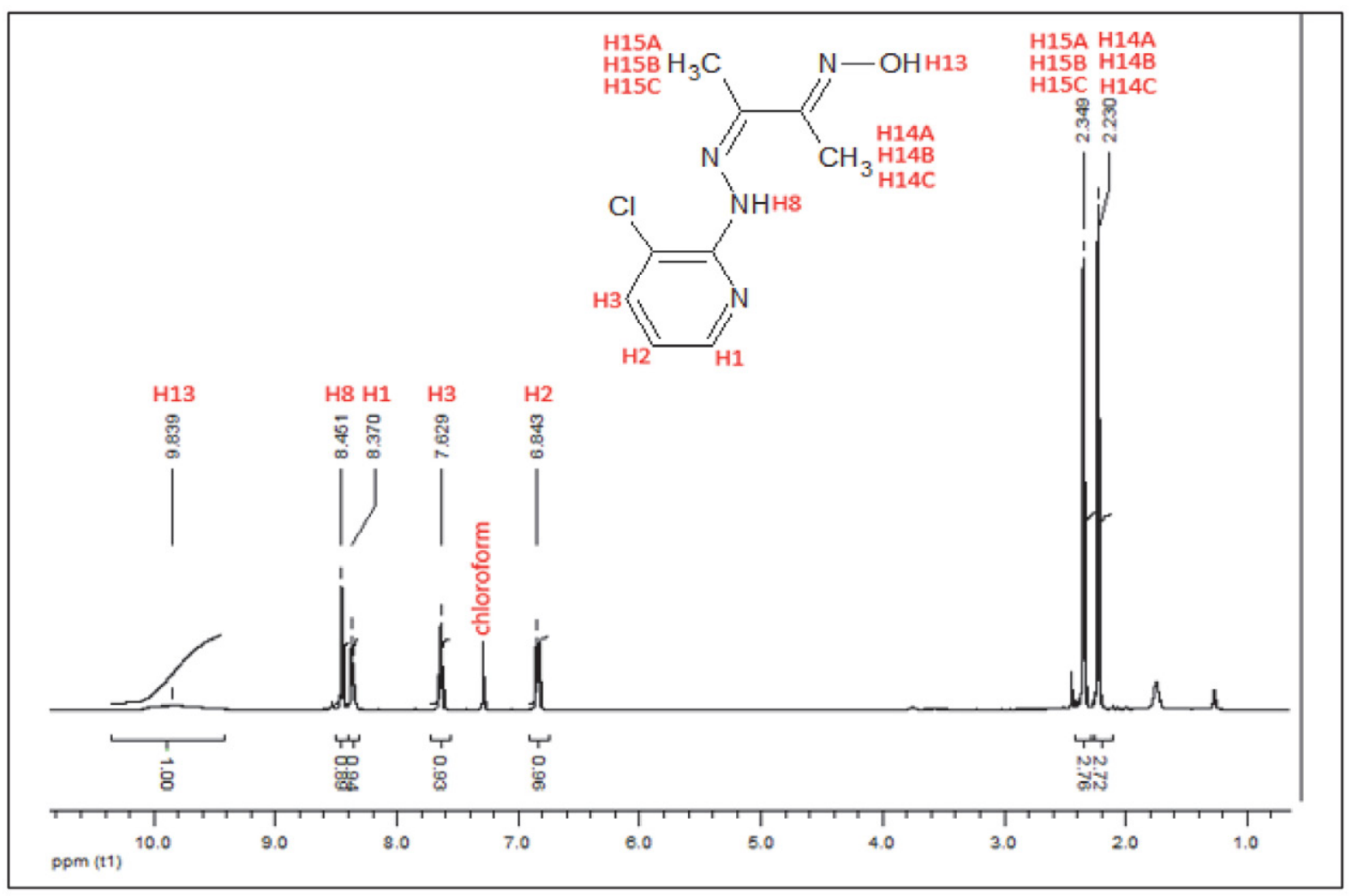

Fig. 4. ${ }^{1} \mathrm{H}-\mathrm{NMR}$ spectrum of $\mathrm{HL}_{1}$ 


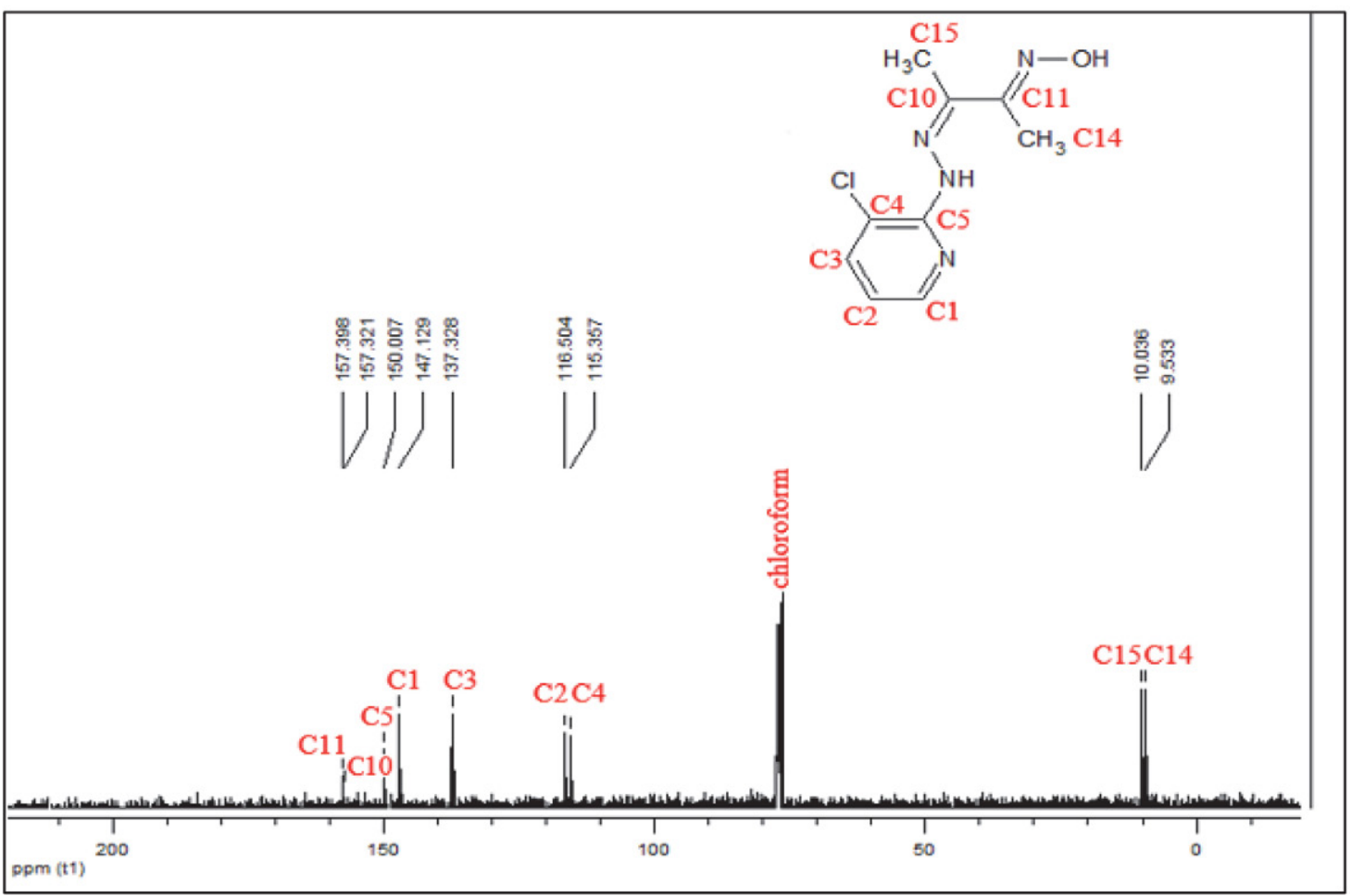

Fig. 5. ${ }^{13} \mathrm{C}-\mathrm{NMR}$ spectrum of $\mathrm{HL}_{1}$

program. ${ }^{34,35}$ The electronic absorption spectra of the ligands, along with the molar extinction coefficient, were obtained in a $5 \times 10^{-5} \mathrm{~mol} \mathrm{~L}^{-1}$ chloroform solution in the wavelength zone (240-480 $\mathrm{nm})$ using the spectroscopic method. ${ }^{23}$ The electron transition possibilities of different compounds were compared using ultraviolet-visible spectroscopy. For $\mathrm{HL}_{1}$ and $\mathrm{HL}_{2}$, slightly different absorption peaks centered at $322,285 \mathrm{~nm}$ and $362,312 \mathrm{~nm}(\varepsilon=42800$, 41100 and $34520,26300 \mathrm{~mol}^{-1} \mathrm{~L} \mathrm{~cm}^{-1}$ ), respectively. The experimental UV-Vis spectra of the $\mathrm{HL}_{1}$ compund and corresponding theoretical calculations are plotted in Fig. 6. The- oretical calculations predicted two peaks at $307,287 \mathrm{~nm}$ and $364,331 \mathrm{~nm}$ which indicated formation of the $\mathrm{HL}_{1}$ and $\mathrm{HL}_{2}{ }^{36}$ The calculated excitation energy, excitation wavelength, oscillator strength with the aid of TD-DFT/B3LYP method are given in Table 4. The electronic absorption spectra of the ligands were defined with two sharp absorption bands. These two bands were observed at 285-312 and 322-362 nm indicative of the $\pi-\pi^{*}$ and $n-\pi^{*}$ transitions, respectively. ${ }^{37}$ While the $\pi-\pi^{*}$ transitions of the ligands originated from the electrons of the pyridine ring, the $n-\pi^{*}$ band occurred due to hydrazone groups $(-\mathrm{NHN}=\mathrm{CH})$ of atoms. ${ }^{38}$
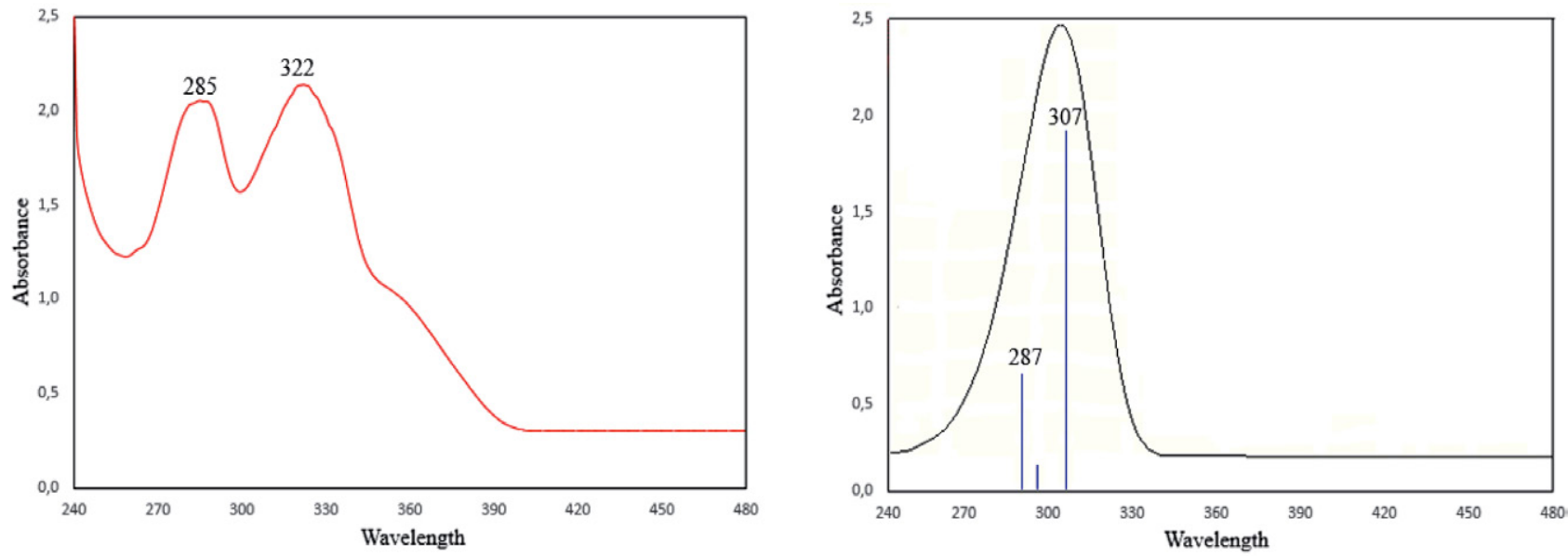

Fig. 6. The (left) experimental and (right) calculated spectrum and observed UltravioleteVisible spectra of the $\mathrm{HL}_{1}$ in $\mathrm{CH}_{2} \mathrm{Cl}_{2}$ solution at room temperature 
Table 4. The experimental and calculated UV-Vis spectral parameters for $\mathrm{HL}_{1}$ and $\mathrm{HL}_{2}$ ligand with its assignments.

\begin{tabular}{lccccc}
\hline Compounds & $\begin{array}{c}\text { Experimental } \\
\boldsymbol{\lambda}(\mathbf{n m})\end{array}$ & $\boldsymbol{\lambda}(\mathbf{n m})$ & $\begin{array}{c}\text { Calculated } \\
\mathbf{E}(\mathbf{e V})\end{array}$ & $\mathbf{f}$ & Assignment \\
\hline $\mathrm{HL}_{1}$ & 285 & 287 & 4.36 & 0.18 & $\pi-\pi^{\star}$ \\
& 322 & 307 & 4.03 & 0.03 & $\mathrm{n}-\pi^{\star}$ \\
$\mathrm{HL}_{2}$ & 312 & 331 & 3.73 & 0.02 & $\pi-\pi^{\star}$ \\
& 362 & 364 & 2.56 & 0.06 & $\mathrm{n}-\pi^{\star}$ \\
\hline
\end{tabular}

\section{5. Mass and FT-IR Spectra}

Mass spectral datas of ligands were obtained by electrospray ionization (ESI) method. The mass exhibited the molecular ion at $\mathrm{m} / \mathrm{z} 226.66284[\mathrm{M}+1]^{+}$and 290.70558 $[\mathrm{M}+1]^{+}$which indicated formation of the $\mathrm{HL}_{1}$ and $\mathrm{HL}_{2}$ (Fig. S1). The moleculer peak of both ligands have a $100 \%$ relative abundance. ${ }^{32}$

Generally compunds are characterized by three IR absorption bands such as $v(\mathrm{O}-\mathrm{H}), v(\mathrm{C}=\mathrm{N})$ and $v(\mathrm{~N}-\mathrm{O})$ stretching vibrations. FT-IR spectrum of the $\mathrm{HL}_{1}$ ligand showed $(\mathrm{C}=\mathrm{N})$ imine $(\mathrm{C}=\mathrm{N})$ oxime peaks at $1596 \mathrm{~cm}^{-1}$ and $1516 \mathrm{~cm}^{-1}$ (Fig. S2). ${ }^{39}$ The bands $3361 \mathrm{~cm}^{-1}$ and 3377 $\mathrm{cm}^{-1}$ were due to $(\mathrm{N}-\mathrm{H})$ vibrations for $\mathrm{HL}_{1}$ and $\mathrm{HL}_{2}$ respectively. Also $(\mathrm{O}-\mathrm{H})$ band of oxime group peak was observed at $3111 \mathrm{~cm}^{-1} \cdot{ }^{33}$ But this peak was not seen at $\mathrm{HL}_{2}$ ligand. At the same time, the bands at $935 \mathrm{~cm}^{-1}$ and 1392 $\mathrm{cm}^{-1}$ assignable to $(\mathrm{N}-\mathrm{O})$ and $\left(\mathrm{NO}_{2}\right)$ vibrations, respectively. The FT-IR spectrum of ligands displayed bands at $2981 \mathrm{~cm}^{-1}$ and $2972 \mathrm{~cm}^{-1}$ which assignable to $\left(\mathrm{C}-\mathrm{H}_{\mathrm{Ar}}\right)$ protons. The medium bands observed at $553 \mathrm{~cm}^{-1}$ and 546 $\mathrm{cm}^{-1}$ assigned to pyridyl rings. For $\mathrm{HL}_{1}$ and $\mathrm{HL}_{2}$, the bands $1454-1451 \mathrm{~cm}^{-1}, 1394-1392 \mathrm{~cm}^{-1}, 1044-1032 \mathrm{~cm}^{-1}$ and $1012-1032 \mathrm{~cm}^{-1}$ assignable to the aromatic pyridine ring. ${ }^{40}$ FT-IR analysis give us the preliminary information about whether this structure is formed or not. Our datas are in agreement with similar oxime and pyridine ligands in the literature. $^{41}$

\section{6. Hirshfeld Surface Analysis}

The surface analysis method is the best way to identify crystal packing and intermolecular interacting in a structure. For this reason, the Hirshfeld surface analysis was performed using CrystalExplorer software (version 17.5). ${ }^{42,43}$ Accordingly, the close correlations between the fragments were quantitatively analyzed. Furthermore, it is one of the computer calculation programs to investigate the mechanism of molecular interactions in proteins and with which intermolecular interactions they could bond to a receptor. In addition, it helps to identify the intermolecular hydrogen bond as well as $\pi-\pi, \mathrm{C}-\mathrm{H} \cdots \mathrm{X}$ (X=halogens) interactions with great importance in crystal package arrangement and stabilization of the molecule. Therefore, $\mathrm{C}(17)-\mathrm{H}(17) \cdots \mathrm{O}(20)$ and $\mathrm{C}(13)-\mathrm{H}(13) \cdots \mathrm{Cl}(11)$ interactions are illustrated in Fig. 7.

Intermolecular interactions of $\mathrm{HL}_{2}$ ligand is presented in Fig. 8 as 2D fingerprints plot. ${ }^{44}$ Blue zone shows intermolecular interaction areas whereas grey zone shows outside of the this interaction area. According to fingerplots studies results of for $\mathrm{HL}_{2} ; \mathrm{Cl} \cdots \mathrm{H} 11,4 \%, \mathrm{H} \cdots \mathrm{H} 28,7 \%$,

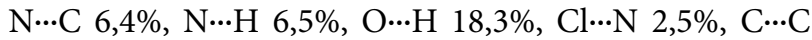
$3,8 \%, \mathrm{C} \cdots \mathrm{H} 15,2 \% .{ }^{22-24}$ Other bondings constituted all interactions by making small contributions on the surface. The highest $\mathrm{H} \cdots \mathrm{H}$ interaction rate (28.7\%) was shown to be derived from the abundance of the $\mathrm{H} \cdot \cdots \mathrm{H}$ interactions in aromatic rings (Fig. S3). ${ }^{4}$

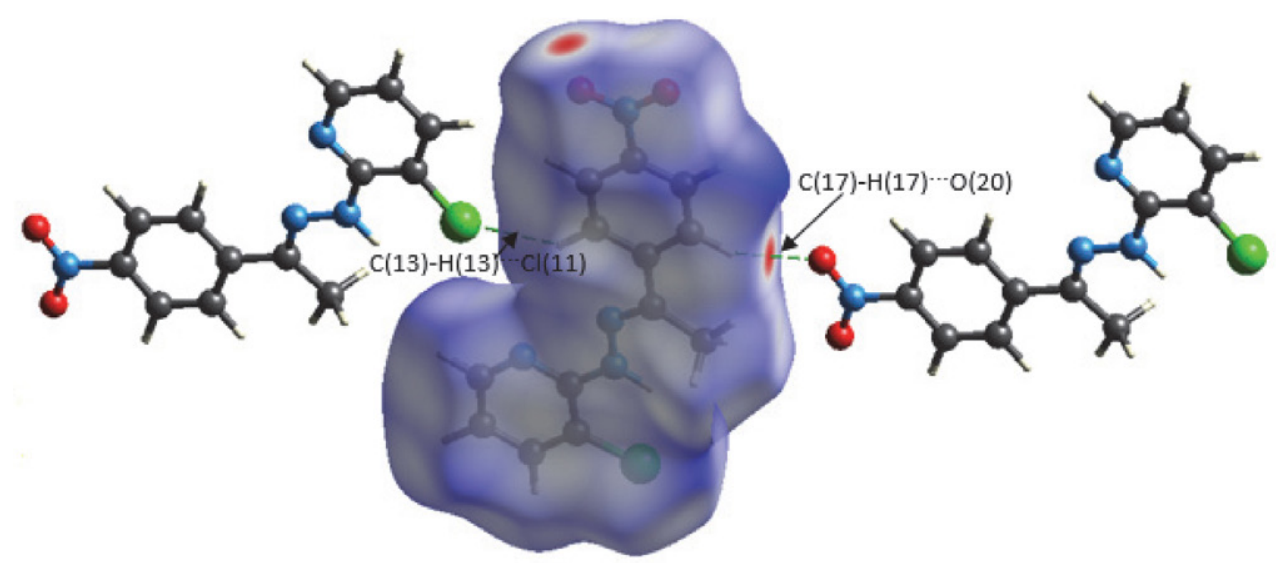

Fig. 7. Close contact of $\mathrm{C}(17)-\mathrm{H}(17) \cdots \mathrm{O}(20)$ and $\mathrm{C}(13)-\mathrm{H}(13) \cdots \mathrm{Cl}(11)$ interactions determined by Hirshfeld surface analysis over dnorm of $\mathrm{HL} \mathrm{L}_{2}$ 


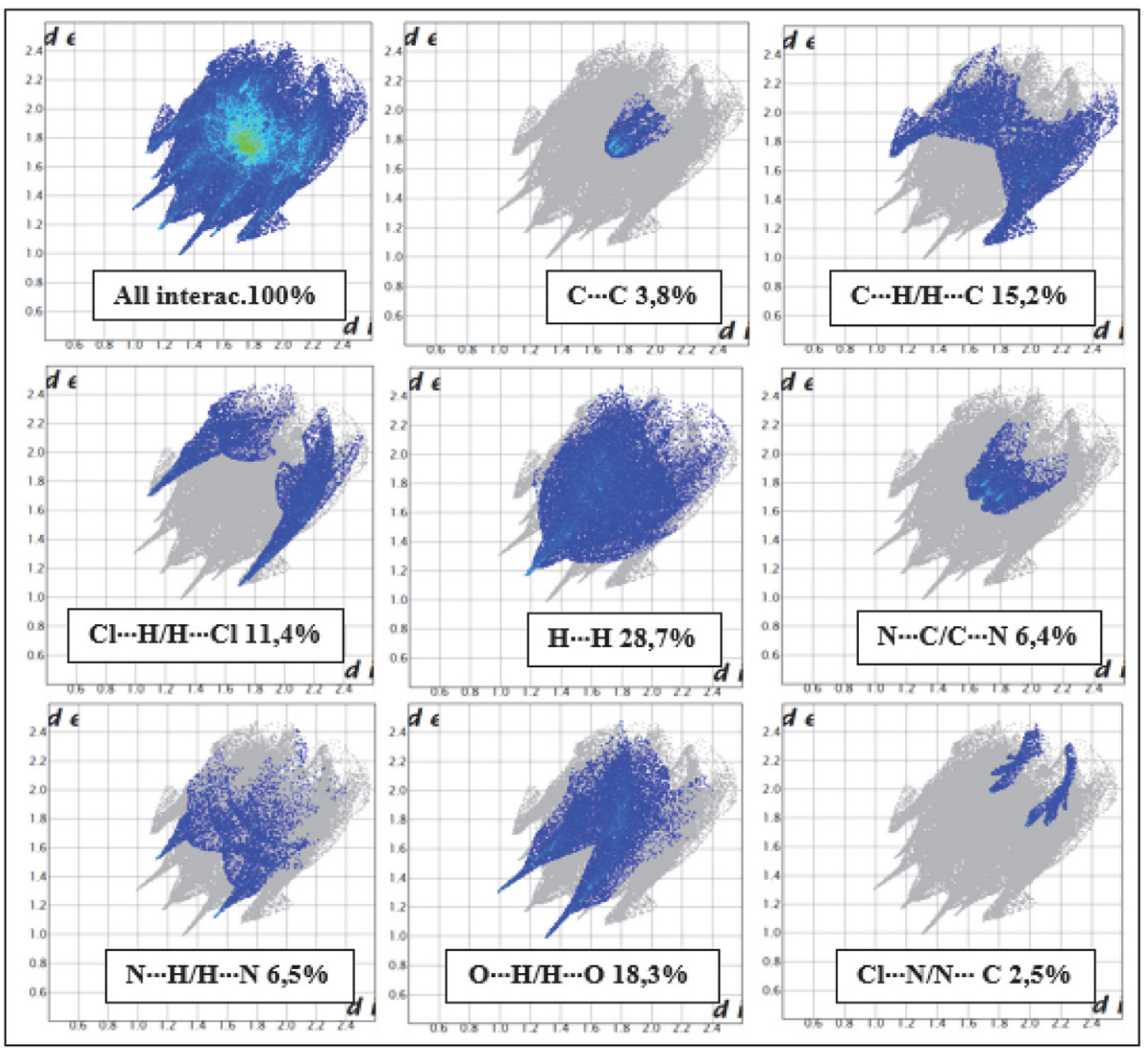

Fig. 8. The $2 \mathrm{D}$ fingerprint plos of the $\mathrm{HL}_{2}$

\section{7. Molecular Electrostatic Potential Analysis}

Molecular electrostatic potential mapping is a method for the observation of the interactions of molecules with each other based on their charge distribution on 3D diagrams. This is an auxiliary method that estimates electrophilic and nucleophilic reactive sites of ligands leading to investigate protein binding and medicine developing by defining hydrogen bond interactions. ${ }^{4,45}$ Electrostatic po-

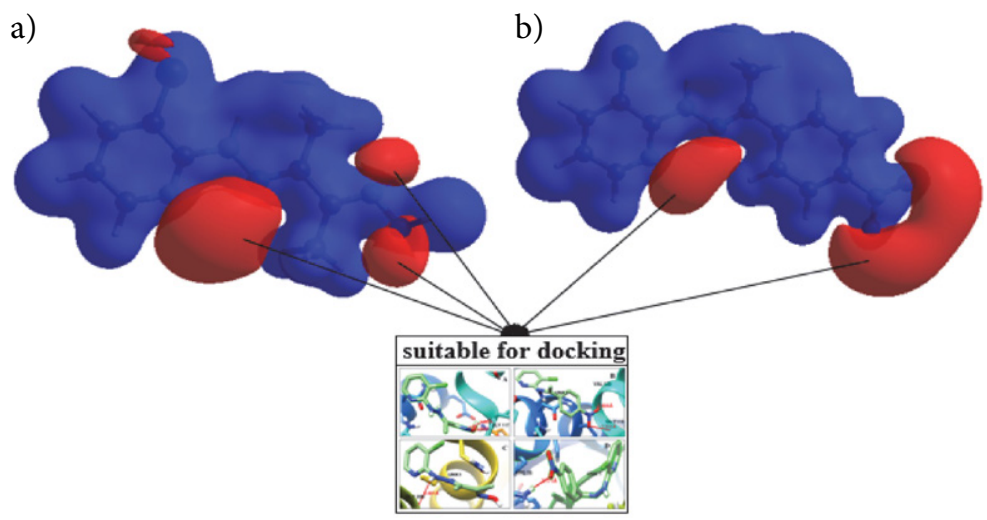

Fig. 9. Electrostatic potential maps of a) $\mathrm{C}_{9} \mathrm{H}_{11} \mathrm{ClN}_{4} \mathrm{O}$ and b) $\mathrm{C}_{13} \mathrm{H}_{11} \mathrm{ClN}_{4} \mathrm{O}_{2}$ 
tential (3D) diagrams of ligands were mapped using the Hartree-Fock theory Slater type orbital-3G base set of Hirshfeld surface analysis by CrystalExplorer software as depicted in Fig. 9. The input file of the geometry was obtained using Tonto. ${ }^{46,47}$ Surface qualification values were set $-0,025-0,025 \mathrm{au}$ and high resolution was selected. When it was performed, the molecule was taken to transparency mode and atoms were made clear. The red color represents the negative electrostatic potential regions and acceptor hydrogen bonds. Moreover, the blue color represents the positive electrostatic potential regions and donor hydrogen bonds. ${ }^{48,49}$ In addition, blue-colored zones are the preferred regions for the nucleophilic attack, while red-colored negative zones are susceptible to electrophilic attack. ${ }^{11}$ Furthermore, red-colored regions have electron-rich atoms or atom groups; therefore, they can easily interact with amino acid residues. Based on the findings of molecular docking studies, hydrogen bond interactions between donor-acceptor confirmed the results of the electrostatic potential analysis as depicted in Fig. 11.

\section{8. Molecular Docking Studies}

In silico docking calculations are of great importance in drug design and medical chemistry fields. Molecular docking is commonly used in the studies carried out on target medicine designing by estimating the binding mechanisms of small molecules on target biologic proteins. ${ }^{50,51}$ Donor-acceptor binding mechanisms create complexations with hydrophobic hydrogen bond and electrostatic interactions. ${ }^{52}$ The current study examined the ligands creating intramolecular hydrogen bonds by targeting the active zones of E. coli DNA GyrB (PDB Code:4WUB) and E. coli FabH (PDB Code:1HNJ) amino acid residues. The protein-related data were obtained from Research Collaboratory for Structural Bioinformatics Protein Data Bank https://www.pdb.org. Molecular docking studies analyzed binding energy, hydrogen bonding, and interactions between the ligands and bacteria. ${ }^{53-56}$ Furthermore, by the calculation of the ligands' lowest binding energy to aminoacids residues, it was determined that which structure has stronger hydrogen bonding and higher binding energy score. ${ }^{57}$ Ligands SMILES formats were created at page https://www.cheminfo.org; it is $\mathrm{C} / \mathrm{C}(=\mathrm{N}$ । $\mathrm{O}) / \mathrm{C}(\mathrm{C})=\mathrm{N} / \mathrm{NclncccclCl}$ for $\mathrm{HL}_{1}$ and $\mathrm{C} / \mathrm{C}(=\mathrm{N} / \mathrm{Nclnc}-$ $\operatorname{ccc} 1 \mathrm{Cl}) \operatorname{coccc}(\mathrm{N}(=\mathrm{O})=\mathrm{O}) \mathrm{cc} 2$ for $\mathrm{HL}_{2}$.

Molecular docking studies were performed Autodock vina program (https://www.vina.scripps.edu). Ligands were converted into mol2 format and prepared for molecular docking at Chimera software program with receptors (E.coli FabH and GyrB) (https://www.cgl.ucsf.edu/chime$\mathrm{ra} /) .{ }^{58}$ In the Dock Prep method, firstly, all nonstandarts and solvents were selected and refined from receptors. Then, protein models were added by the selection of all hydrogen atoms (also considered H-bonds) and Gasteiger charges. Docking studies were conducted by targeting ligand receptors and binding the most convenient coordinates. ${ }^{59}$ While defining an approximate donor and acceptor binding zone in in-silico studies, docking parameters are of great importance. Different types of grid box values were applied for the best and most accurate binding. The application of target protein binding zones (as a great scale) in a cubic box resulted in the best binding; however, this method requires a long computer calculation..$^{60,61}$ The grid box values of ligands applied to $E$. coli GyrB receptor were $10,25,-10$ at the center with a grad spacing of 0.375 $\AA$ including default the sizes of $40,40,40$ for $\mathrm{HL}_{1}$ and $\mathrm{HL}_{2}$. The same method was employed to E. coli FabH receptor reporting the values of $30,15,30$ at the center with the sizes of 30, 30, 30 for $\mathrm{HL}_{1}$ and $\mathrm{HL}_{2}$. In addition, default values were used for other parameters. Root-mean-square deviation were selected as minumum value. The binding energy values of -7.9 and $-8.8 \mathrm{kcal} / \mathrm{mol}$ were applied by $\mathrm{HL}_{1}$ and $\mathrm{HL}_{2}$ ligands to the $\mathrm{GyrB}$ receptor, respectively. Fig. 10 illustrates the hydrophobicity surface area of $\mathrm{HL}_{1}$ inside $\mathrm{GyrB}$ and $\mathrm{FabH}$ proteins. The binding energy values
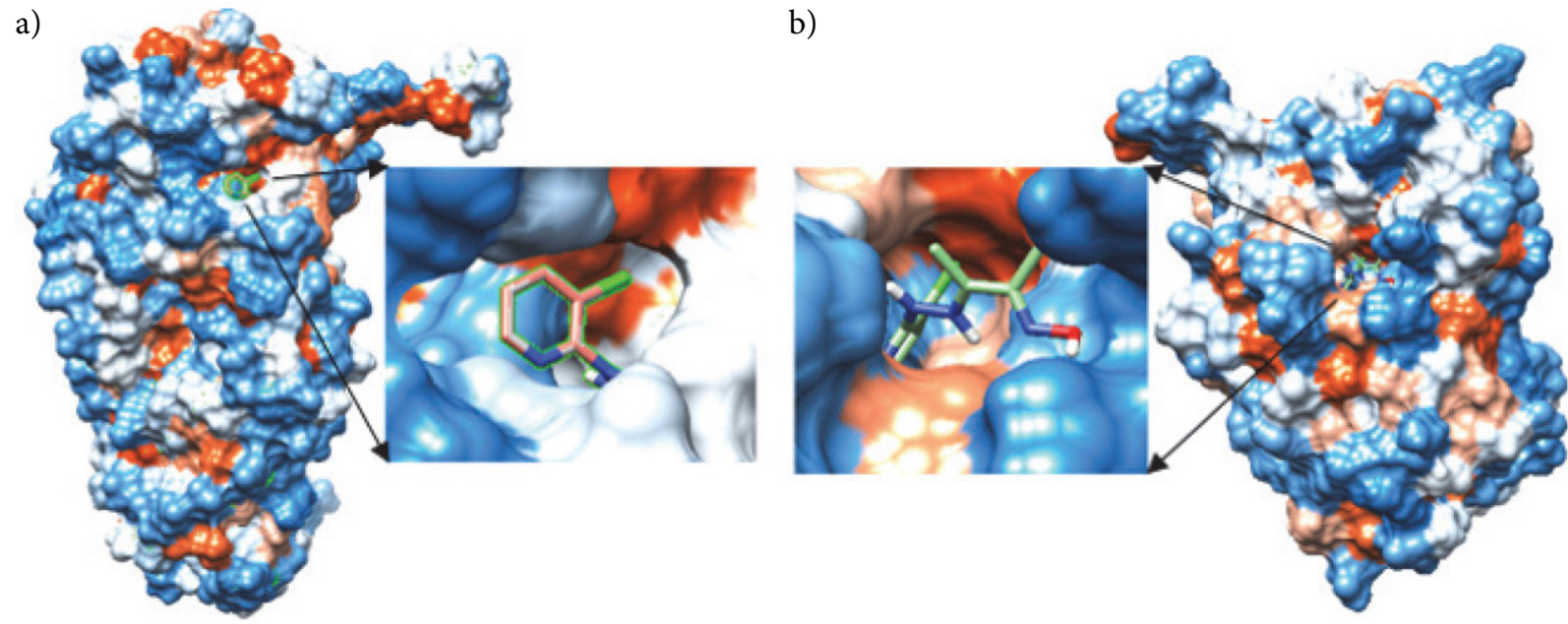

Fig. 10. Illustration of hydrophobicity surface area of $\mathrm{HL}_{1}$ inside a) gyrase subunit $\mathrm{B}$ and b) beta-ketoacyl-acyl carrier protein synthase III proteins

Topal: Synthesis, Crystallographic Structure, Hirshfeld Surface ... 

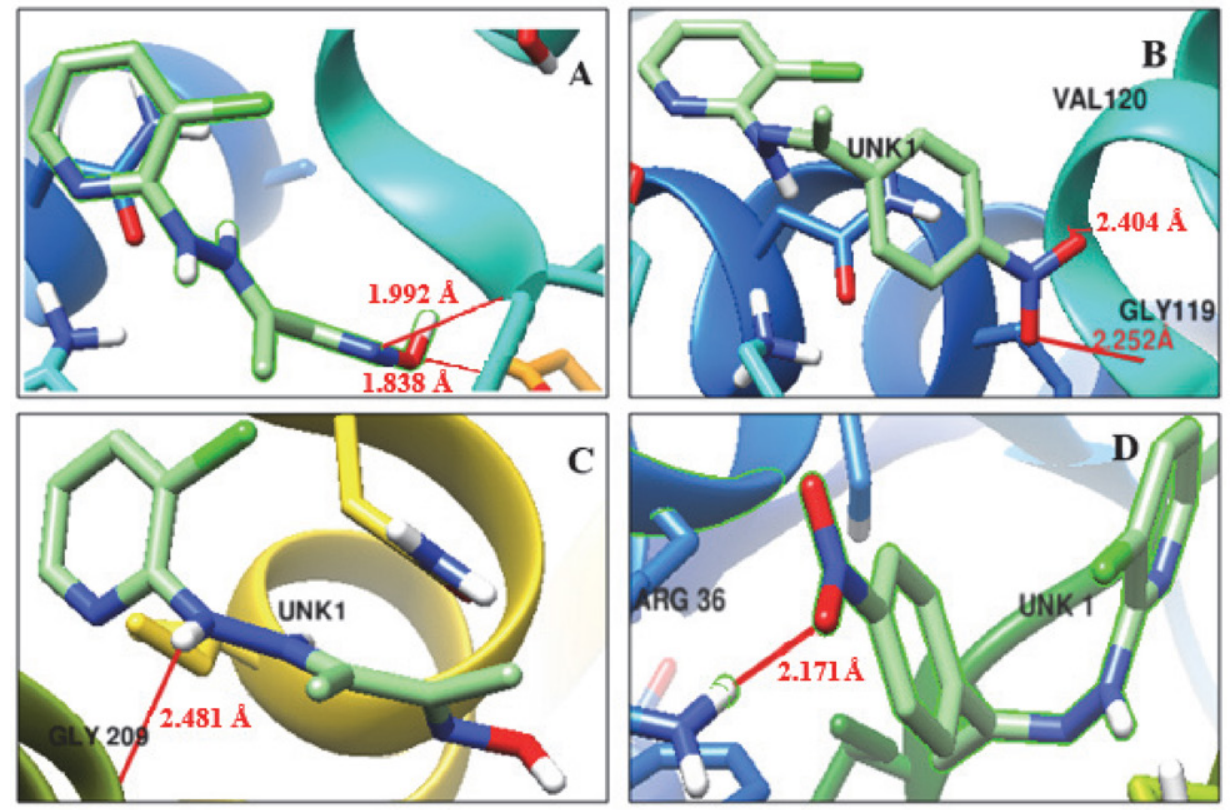

Fig. 11. Results of molecular docking for a) $\mathrm{HL}_{1}$-gyrase subunit $\mathrm{B}$ (GyrB) (4WUB), b) $\mathrm{HL}_{2}$-GyrB (4WUB), c) $\mathrm{HL}_{1}$ - beta-ketoacyl-acyl carrier protein synthase III (FabH) (1HNJ), and d) $\mathrm{HL}_{2}-\mathrm{FabH}(1 \mathrm{HNJ})$

of -6.1 and $-6.8 \mathrm{kcal} / \mathrm{mol}$ were applied by $\mathrm{HL}_{1}$ and $\mathrm{HL}_{2}$ ligands to the FabH receptor, respectively. The binding interactions and docking poses are depicted in Fig. 11. Since the ligands bind to the GyrB receptor with higher binding energy than that reported for the FabH receptor, there was a better docking to the ligands-GyrB complex. While there were two hydrogen bonds in the complex that ligands made with $4 \mathrm{WUB}$ protein, $1 \mathrm{HNJ}$ protein had one hydrogen bond. This finding proved that this effect increases the binding energy value. As the binding energy value enhances, the binding score increases indicating a better docking. ${ }^{41,62}$ Therefore, the binding energy of $\mathrm{HL}_{2}$ was higher than that reported for $\mathrm{HL}_{1}$ which is considered a better docking. The other reason behind that is believed to be the electron density and unpaired electron couples of two oxygen atoms that bond to the nitrogen atom of $\mathrm{HL}_{2}{ }^{63} \mathrm{In}$ a study carried out by Fathima et al. (2018), docking results were observed to be -8.4 and $-8.5 \mathrm{kcal} / \mathrm{mol}$ for $2 \mathrm{AB}$ P2C-1HNJ and 2ABHB-1HNJ, respectively. ${ }^{54}$
The $\mathrm{HL}_{1}$ created a hydrogen bond to GLY 117 and GLN 335.A HE22 amino acid residues of 4WUB protein with $\mathrm{N} 12$ and $\mathrm{O} 13$ atoms and binding lengths were observed as $1.992 \AA$ and $1.838 \AA$, respectively. The $\mathrm{HL}_{2}$ bonded to GLY 119 and VAL 120 amino acid residues of 4 WUB proteins with $\mathrm{O} 19$ and $\mathrm{O} 20$ atoms and binding lengths were observed as $2.252 \AA$ and $2.404 \AA$. In another study conducted by Metelytsia et al. (2020), the binding of ligands to the regions of amino acid residues were reported as GLY 119 and His 116. This finding is similar to the results of docking investigations in the current study in terms of attachment regions. ${ }^{52}$ The $\mathrm{HL}_{1}$ and $\mathrm{HL}_{2}$ created a hydrogen bond to GLY 209, ARG 36.A HH22 amino acid residues of $1 \mathrm{HNJ}$ receptor with $\mathrm{N} 8$ and $\mathrm{O} 19$ atoms and binding lengths were observed as $2.481 \AA$ and $2.171 \AA$, respectively. Donor and acceptor hydrogen binding interactions are shown as Table $5 .^{64}$ The findings of docking studies confirmed that the results and interactions of molecular electrostatic potential generally occur in red regions. The

Table 5. AutoDock results showing Compound-Protein name, Binding site of protein, Binding site of Ligand, Type of interactions, Bond length, Binding energy.

\begin{tabular}{lcllcl}
\hline $\begin{array}{l}\text { Compound- } \\
\text { Protein name }\end{array}$ & $\begin{array}{c}\text { Binding site of } \\
\text { protein }\end{array}$ & $\begin{array}{c}\text { Binding site of } \\
\text { Ligand }\end{array}$ & $\begin{array}{c}\text { Type of } \\
\text { interaction }\end{array}$ & $\begin{array}{c}\text { Bond } \\
\text { length }(\AA)\end{array}$ & $\begin{array}{c}\text { Binding energy } \\
(\text { Kcal/Mol) }\end{array}$ \\
\hline $\mathrm{HL}_{1}-4 \mathrm{WUB}$ & GLY 117 & UNK1-N12 atom & Hydrogen bond & 1.992 & -7.9 \\
& GLN 335.A HE22 & UNK1-O13 atom & Hydrogen bond & 1.838 & -8.8 \\
$\mathrm{HL}_{2}-4 \mathrm{WUB}$ & GLY 119 & UNK1-O19 atom & Hydrogen bond & 2.252 & 2.404 \\
& VAL 120 & UNK1-O20 atom & Hydrogen bond & 2.481 & -6.1 \\
$\mathrm{HL}_{1}-1 \mathrm{HNJ}$ & GLY 209 & UNK1-N8 atom & Hydrogen bond & 2.171 & -6.8 \\
$\mathrm{HL}_{2}-1 \mathrm{HNJ}$ & ARG 36.A HH22 & UNK1-O19 atom & Hydrogen bond & \\
\hline
\end{tabular}


findings of docking studies also revealed that ligands are potential inhibitors against E. coli DNA GyrB and E. coli FabH. ${ }^{65}$

\section{9 Drug-Likeness and Biological Activity}

Drug-likeness and bioactivity of ligands were obtained from molinspiration (https://www.molinspiration. com/cgi-bin/properties). Although the parameters of druglikeness cannot estimate the biological activity of each compound, it is one of the most successful and efficient methods for the analysis of compounds with medicinal potential through the determination of pharmacokinetic characteristics. Based on Table 6 , the parameters of drug-likeness and biologic activity for the compounds in the present study (miLogP, TPSA, nAtoms, MW, nON, nOHNH, nviolations, and rotb) and (enzyme inhibitor, protease inhibitor, nuclear receptor ligand, kinase inhibitor, ion channel modulator, and GPRC ligand). The aforementioned findings have been the first obtained data regarding the medicinal potential of the compounds. ${ }^{66}$ The values of drug-likeness were determined in this study, and the ligands were examined regarding midicinal potential with the consideration of these values. In this sense, the miLogP parameter, which is the capacity of penetrating the cell membrane, is expected to be under 5 . In this regard, the values of miLogP parameter were reported as 1.81 and 3.37 for $\mathrm{HL}_{1}$ and $\mathrm{HL}_{2}$, respectively. The polar surface area (TPSA) represents the hydrogen bonding potential of a compound. Accordingly, the TPSA values were observed as 69.88 and $83.11 \mathrm{~A}^{2}$ for $\mathrm{HL}_{1}$ and $\mathrm{HL}_{2}$, respectively. These values were below the $160 \mathrm{~A}^{2}$ limit defined for TPSA and at a good performance. ${ }^{67-70}$ Although miLogP and TPSA are not sufficient criteria for the investigation of druglikeness, they are two important parameters to represent oral absorption in cells. ${ }^{71}$ The number of acceptor hydrogen bonds was set to $\mathrm{nON} \leq 10$, and the number of donor hydrogen bonds was set to $\mathrm{nOHNH} \leq 5$. In this study, the obtained results were below the aforementioned values. ${ }^{72}$ Low molecule weight is important in terms of

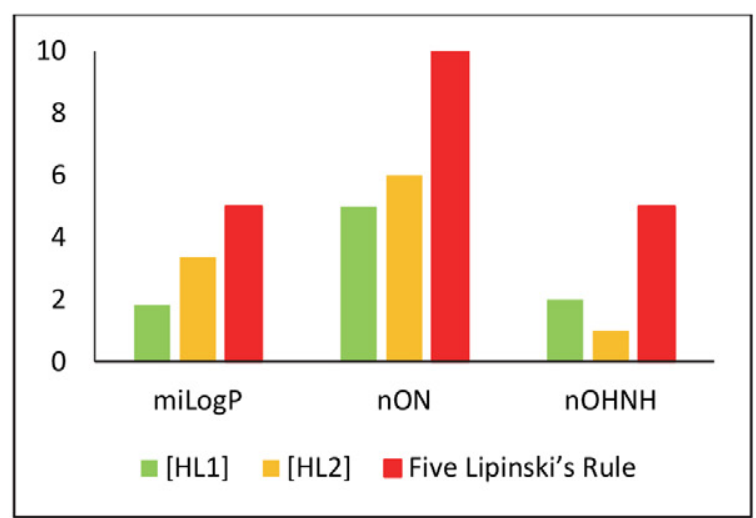

Fig. 12. Druglikeness scores of ligands according to Lipinski's rule of five
Table 6. Calculated drug-likeness parametres and Bioactivity Score of ligands.

\begin{tabular}{lcc}
\hline & $\mathbf{H L}_{\mathbf{1}}$ & $\mathbf{H L}_{\mathbf{2}}$ \\
\hline miLog $_{\mathrm{P}}$ & 1.81 & 3.37 \\
TPSA & 69.88 & 83.11 \\
natoms & 15 & 20 \\
$\mathrm{MW}$ & 226,67 & 290.71 \\
$\mathrm{nON}$ & 5 & 6 \\
nOHNH & 2 & 1 \\
nviolations & 0 & 0 \\
nrotb & 3 & 4 \\
GPCR ligand & -0.78 & -0.70 \\
Ion channel modulator & -0.62 & -0.70 \\
Kinase inhibitor & -0.74 & -0.55 \\
Nuclear receptor ligand & -1.32 & -0.94 \\
Protease inhibitor & -1.32 & -1.02 \\
Enzyme inhibitor & -0.43 & -0.49 \\
\hline
\end{tabular}

easy transport, diffusion, and absorption of the molecule. The values of molecular weight are expected to be $<500$ $\mathrm{Da}$. In this study, the molecular weights of the ligands were lower than the aforementioned value. The ligands were reported with successful results according to Lipinski's rule of five. Based on Fig. 12, the red column shows Lipinski's rule of five, and the green and red columns depict the druglikeness score of the ligands. ${ }^{68}$

If the value of violations equals 0 , it shows that crystallized compounds can easily bond to the receptor. This value was reported as 0 for the compounds of the present study. The number of rotatable bonds is a simple topological value and measurement of flexibility. ${ }^{73}$ If the bioactivity results of the compounds are $>0,-5.0-0.0$, and $<-5.0$, they are considered active, medium active, and not active, respectively. All the results of biological activity parameters were within the range of $-5.0-0.0$; therefore, the ligandswere regarded as medium active. ${ }^{74}$ As a result, it was concluded that the ligands of the current study obtained satisfactory druglikeness scores and properties to be considered medicine potential agents.

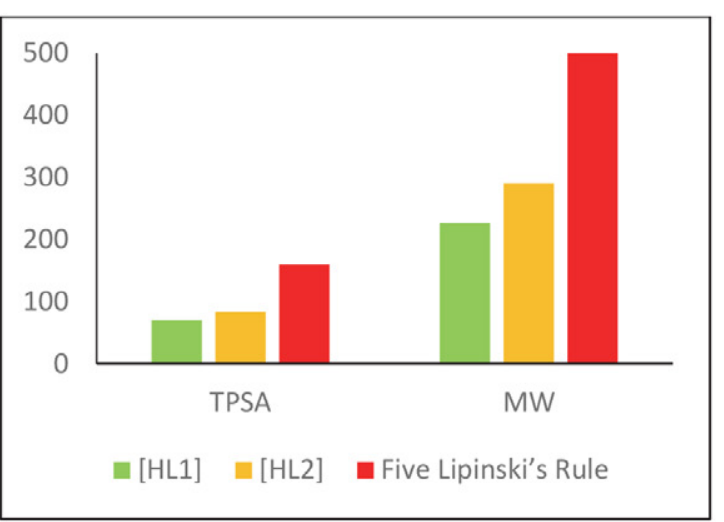

Topal: Synthesis, Crystallographic Structure, Hirshfeld Surface ... 


\section{Conclusion}

In this work, the new (2E,3Z)-3-[2-(3-chloropyridin-2-yl)hydrazinylidene]- $N$-hydroxybutan-2-imine and 3-chloro-2-\{(2Z)-2-[1-(4-nitrophenyl)ethylidene]hydrazinyl\}pyridine ligands were synthesized and characterized by elemental analysis, LC/MS-MS, FT-IR, ${ }^{1} \mathrm{H}-\mathrm{NMR}$, ${ }^{13} \mathrm{C}$-NMR and UV-Vis. $\mathrm{HL}_{2}$ was also determinated by single-crystal X-ray diffraction (XRD) and crystallized in the space group $\mathrm{P} 2_{1} / \mathrm{c}$ of with $\mathrm{Z}=4$ and was linked into (3-D) network by $\mathrm{C}-\mathrm{H} \cdots \mathrm{O}$ intermoleculer hydrogen bonding interactions. Additionally, $\mathrm{Cl} \cdots \mathrm{H}$ 11,4\%, $\mathrm{H} \cdots \mathrm{H}$ 28,7\%, N $\cdots \mathrm{C}$

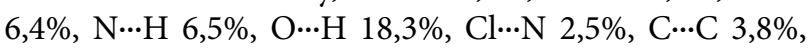
C...H 15,2\% reciprocal influence were revealed by Hirshfeld Surface Analysis. The mass spectra of the ligands showed the main peaks that corresponding to $[\mathrm{M}+1]^{+}$. UV-Vis studies demonsrated that the $\pi-\pi^{*}$ and $n-\pi^{*}$ transitions appearing at $285,312 \mathrm{~nm}$ and $322,362 \mathrm{~nm}$, respectively. The obtained experimental results of the present study were fully compatible with the theoretical results. The binding energy values of -7.9 and $-8.8 \mathrm{kcal} / \mathrm{mol}$ were applied by $\mathrm{HL}_{1}$ and $\mathrm{HL}_{2}$ ligands to the GyrB receptor, respectively. Moreover, the binding energy values of -6.1 and $-6.8 \mathrm{kcal} / \mathrm{mol}$ were applied by $\mathrm{HL}_{1}$ and $\mathrm{HL}_{2}$ ligands to the $\mathrm{FabH}$ receptor. The increase at binding energy values is resulted with a better docking. Therefore, $\mathrm{HL}_{2}$ has a better docking ability than $\mathrm{HL}_{1}$. The synthesized ligands are compatible with Lipinski's rule of five and have features to be a good drug-likeness scores. The bioactivity scores of the ligands are within the range of -5.0-0.0; consequently, the pharmacokinetic and pharmacological properties of the ligands are appropriate leading to be considered potential drug agents.

\section{References}

1. H. Mansouri-Torshizi, M. Moghadam, A. Divsalar and A. Saboury, Acta Chim. Slov., 2011, 58, 811-822.

2. E. Gina Vasile Scăet, M. C. Chifiriuc, C. Bleotu, C. Kamerzan, T. Luminița Măru, C. G. Daniliuc, C. Maxim, L. Calu, R. Olar and M. Badea, Molecules, 2018, 23, 1-18.

DOI:10.3390/molecules23010157

3. B. A. V Lima, A. E. Graminha, A. Kuznetsov, J. Ellena, F. R. Pavan, C. Q. F. Leite and A. A. Batista, J. Braz. Chem. Soc., 2016, 27, 30-40. DOI:10.5935/0103-5053.20150237

4. M. Venkateshan, R. V. Priya, M. Muthu, J. Suresh and R. R. Kumar, Chem. Data Collect., 2019, 23, 100262.

DOI:10.1016/j.cdc.2019.100262

5. L. Metelytsia, D. Hodyna, I. Dobrodub, I. Semenyuta, M. Zavhorodnii, V. Blagodatny, V. Kovalishyn and O. Brazhko, Comput. Biol. Chem., 2020, 85, 107224.

DOI:10.1016/j.compbiolchem.2020.107224

6. S. S. Kumar, S. Athimoolam and B. Sridhar, Spectrochim. Acta. A. Mol. Biomol. Spectrosc., 2015, 146, 204-213.

DOI:10.1016/j.saa.2015.02.104
7. A. M. Netto, S. M. C. M. Bicalho, C. L. Filgueiras and J. C. Machado, Chem. Phys. Lett., 1985, 119, 507-510.

DOI:10.1016/0009-2614(85)85378-1

8. N. Wazzan, Asian J. Chem., 2015, 27, 4641-4656. DOI:10.14233/ajchem.2015.19304

9. G. Vadivelan, M. Saravanabhavan, V. Murugesan and M. Sekar, Spectrochim. Acta. A. Mol. Biomol. Spectrosc., 2015, 145, 461-466. DOI:10.1016/j.saa.2015.03.045

10. K. M, S. Saxena, R. S and V. R, Curr. Med. Chem. - Anti-Infective Agents, 2003, 2, 269-286.

DOI: $10.2174 / 1568012033483015$

11. S. Madhankumar, P. Muthuraja and M. Dhandapani, J. Mol. Struct., 2020, 1201, 127151.

DOI:10.1016/j.molstruc.2019.127151

12. M. Akram, S. Niaz, M. Adeel, M. N. Tahir, I. Ullah, M. A. Ullah, S. Subashchandrabose and G. Uddin, J. Mol. Struct., 2019, 127448. DOI:10.1016/j.molstruc.2019.127448

13. L. K. McLellan and D. A. Hunstad, Trends Mol. Med., 2016, 22, 946-957. DOI:10.1016/j.molmed.2016.09.003

14. V. L. Tchesnokova, L. L. Ottley, K. Sakamoto, J. Fierer, E. Sokurenko and M. A. Liss, Urology, 2015, 86, 1200-1205. DOI:10.1016/j.urology.2015.07.008

15. Y. Zhang, X. Zhang, L. Qiao, Z. Ding, X. Hang, B. Qin, J. Song and J. Huang, J. Mol. Struct., 2019, 1176, 335-345.

DOI:10.1016/j.molstruc.2018.08.069

16. K. M. Hillgren, A. Kato and R. T. Borchardt, Med. Res. Rev., 1995, 15, 83-109. DOI:10.1002/med.2610150202

17. N. Srinivasan, S. Thirumaran and S. Ciattini, J. Mol. Struct., 2009, 936, 234-238. DOI:10.1016/j.molstruc.2009.08.001

18. B. Guhathakurta, C. Biswas, J. P. Naskar, L. Lu and M. Zhu, J. Chem. Crystallogr., 2011, 41, 1355-1359.

DOI:10.1007/s10870-011-0103-x

19. O. V Dolomanov, L. J. Bourhis, R. J. Gildea, J. A. K. Howard and H. Puschmann, J. Appl. Crystallogr., 2009, 42, 339-341. DOI:10.1107/S0021889808042726

20. L. Palatinus, S. J. Prathapa and S. van Smaalen, J. Appl. Crystallogr., 2012, 45, 575-580.

DOI:10.1107/S0021889812016068

21. C. F. Macrae, I. J. Bruno, J. A. Chisholm, P. R. Edgington, P. McCabe, E. Pidcock, L. Rodriguez-Monge, R. Taylor, J. Van De Streek and P. A. Wood, J. Appl. Crystallogr., 2008, 41, 466470. DOI:10.1107/S0021889807067908

22. E. Matamala-Cea, F. Valenzuela-Godoy, D. González, R. Arancibia, V. Dorcet, J. R. Hamon and N. Novoa, J. Mol. Struct., 2020, 1201, 127139. DOI:10.1016/j.molstruc.2019.127139

23. Y. Y. Cai, L. Y. Xu, L. Q. Chai and Y. X. Li, J. Mol. Struct., 2020, 1204, 127552. DOI:10.1016/j.molstruc.2019.127552

24. Q. Wu, Y. Tang and Q. Zi, Polyhedron, 2019, 166, 123-129. DOI:10.1016/j.poly.2019.03.021

25. N. Bandyopadhyay, A. B. Pradhan, S. Das, L. Lu, M. Zhu, S. Chowdhury and J. P. Naskar, J. Photochem. Photobiol. B Biol., 2016, 160, 336-346.

DOI:10.1016/j.jphotobiol.2016.04.026

26. S. Chantrapromma, P. Jansrisewangwong and H.-K. Fun, Acta Crystallogr. Sect. E. Struct. Rep. Online, 2010, 66, o2994-5. DOI:10.1107/S1600536810043266 
27. T. Karakurt, S. Meral, A. A. Agar, Süleyman Demirel Univ. J. Nat. Appl. Sci., 2019, 23, 505-514.

DOI:10.19113/sdufenbed.530279

28. E. Szłyk, A. Wojtczak, A. Surdykowski and M. Goździkiewicz, Inorganica Chim. Acta, 2005, 358, 467-475.

DOI:10.1016/j.ica.2004.07.065

29. L. Chai, Y. Zhang, J. Tong and G. Liu, Z. Naturforsch., 2013, 68b, 239-244. DOI:10.5560/znb.2013-2301

30. P. Pattanayak, J. L. Pratihar, D. Patra, P. Brandão and V. Felix, Inorganica Chim. Acta, 2014, 418, 171-179.

DOI:10.1016/j.ica.2014.04.021

31. H. Wang, H. Xiao, N. Liu, B. Zhang and Q. Shi, Open J. Inorg. Chem., 2015, 05, 63-73. DOI:10.4236/ojic.2015.53008

32. T. Topal, E. Karapinar, J. Turkish Chem. Soc. Sect. A Chem., 2018, 5, 785-802. DOI:10.18596/jotcsa.324878

33. T. Topal, H. H. Kart, P. Tunay Taşlı and E. Karapınar, Opt. Spectrosc., 2015, 118, 897-912. DOI:10.1134/S0030400X15060223

34. M. J. Frisch et al., G16_B01. Gaussian 16, Revision B.01 Gaussian, Inc., Wallingford CT, 2016.

35. J. B. Foresman, A. E. Frisch., Exploring chemistry with electronic structure methods. Gaussian, Inc., 1996.

36. R. Mohamed Asath, R. Premkumar, T. Mathavan and A. Milton Franklin Benial, Spectrochim. Acta - Part A Mol. Biomol. Spectrosc., 2017, 175, 51-60.

DOI:10.1016/j.molstruc.2017.04.117

37. E. Erdem, M. Akarsu, R. Kılınçarslan, İ. Kayağil, İ. Kara and S. Söyleyici, Croat. Chem. Acta, 2016, 89, 55-64.

DOI: $10.5562 / \mathrm{cca} 2820$

38. S. Shit, M. Nandy, C. Rizzoli and S. Mitra, J. Chem. Sci., 2016, 128, 913-920. DOI:10.1007/s12039-016-1082-4

39. E. Karapinar, O. Karabulut and N. Karapinar, Hindawi Publ. Corp. J. Chem. 2013, 2013. DOI:10.1155/2013/256983

40. H. Briseño-Ortega, L. Juárez-Guerra, S. Rojas-Lima, L. H. Mendoza-Huizar, R. A. Vázquez-García, N. Farfán, R. Arcos-Ramos, R. Santillan and H. López-Ruiz, J. Mol. Struct., 2018, 1157, 119-126. DOI:10.1016/j.molstruc.2017.12.059

41. R. Mohamed Asath, R. Premkumar, T. Mathavan and A. Milton Franklin Benial, Spectrochim. Acta - Part A Mol. Biomol. Spectrosc., 2017, 175, 51-60. DOI:10.1016/j.saa.2016.11.037

42. P. Muthuraja, M. Sethuram, T. Shanmugavadivu and M. Dhandapani, J. Mol. Struct., 2016, 1122, 146-156.

DOI:10.1016/j.molstruc.2016.05.083

43. M. A. Spackman and D. Jayatilaka, CrystEngComm, 2009, 11, 19-32. DOI:10.1039/B818330A

44. J. J. McKinnon, M. A. Spackman and A. S. Mitchell, Acta Crystallogr. Sect. B., 2004, 60, 627-668.

DOI:10.1107/S0108768104020300

45. R. Daengngern and N. Kungwan, J. Lumin., 2015, 167, 132139. DOI:10.1016/j.jlumin.2015.06.001

46. J. J. McKinnon, D. Jayatilaka and M. A. Spackman, Chem. Commun., 2007, 3814-3816. DOI:10.1039/b704980c

47. D. Jayatilaka and D. J. Grimwood, Comput. Sci. ICCS, 2003, 142-151. DOI:10.1007/3-540-44864-0_15

48. M. A. Spackman, J. J. McKinnon and D. Jayatilaka, CrystEngComm, 2008, 10, 377-388. DOI:10.1039/b715227b
49. S. M. Kumar, B. C. Manjunath, G. S. Lingaraju, M. M. M. Abdoh and M. P. Sadashiva, Cryst. Struct. Theory Appl. 2013, 2013, 124-131. DOI:10.4236/csta.2013.23017

50. S. Vilar, G. Cozza and S. Moro, Curr. Top. Med. Chem., 2008, 8, 1555-1572. DOI:10.2174/156802608786786624

51. R. Thomsen and M. H. Christensen, J. Med. Chem., 2006, 49, 3315-3321. DOI:10.1021/jm051197e

52. P. Sjoberg and P. Politzer, J. Phys. Chem., 1990, 94, 3959-3961. DOI:10.1021/j100373a017

53. E. G. Sağlam, E. Bulat, C. T. Zeyrek, H. Dal and T. Hökelek, J. Mol. Struct., 2019, 1178, 112-125.

DOI:10.1016/j.molstruc.2018.09.084

54. K. S. F. M. Sathiyendran, K. Anitha, Mater. Sci. Eng. C., 2018, 91, 103-114. DOI:10.1016/j.msec.2018.05.035

55. I. Ali, M. N. Lone, Z. A. Alothman and A. Alwarthan, J. Mol. Liq., 2017, 234, 391-402.

DOI:10.1016/j.molliq.2017.03.112

56. M. M. Silva, F. C. Savariz, E. F. Silva-JÃ|textordmasculinenior, T. M. de Aquino, M. H. Sarragiotto, J. C. C. Santos and I. M. Figueiredo, J. Braz. Chem. Soc., 2016, 27, 1558-1568.

57. M. K. Bhattacharyya, D. Dutta, S. M. Nashre-ul-Islam, A. Frontera, P. Sharma, A. K. Verma and A. Das, Inorganica Chim. Acta, 2020, 501, 119233. DOI:10.1016/j.ica.2019.119233

58. R. S. Soderquist and A. Eastman, Mol. Cancer Ther., 2016, 15, 2011-2017. DOI:10.1158/1535-7163.MCT-16-0031

59. N. Shahabadi and M. Falsafi, Spectrochim. Acta - Part A Mol. Biomol. Spectrosc., 2014, 125, 154-159.

DOI:10.1016/j.saa.2014.01.066

60. W. P. Feinstein and M. Brylinski, J. Cheminform., 2015, 7. DOI:10.1186/s13321-015-0067-5

61. D. Plewczynski, M. Lazniewski, R. Augustyniak and K. Ginalski, J. Comput. Chem., 2011, 32, 742-755.

DOI: $10.1002 /$ jcc. 21643

62. B. Kurt, H. Temel, M. Atlan and S. Kaya, J. Mol. Struct., 2020, 1209, 127928. DOI:10.1016/j.molstruc.2020.127928

63. N. Das, P. K. Jena and S. K. Pradhan, Heliyon, 2020, 6, e02693. DOI:10.1016/j.heliyon.2019.e02693

64. A. De, H. P. Ray, P. Jain, H. Kaur and N. Singh, J. Mol. Struct., 2020, 1199, 126901.

DOI:10.1016/j.molstruc.2019.126901

65. M. Parveen, A. Aslam, A. Ahmad, M. Alam, M. R. Silva and P. S. P. Silva, J. Mol. Struct., 2020, 1200, 127067.

DOI:10.1016/j.molstruc.2019.127067

66. S. M. Hiremath, A. S. Patil, C. S. Hiremath, M. Basangouda, S. S. Khemalapure, N. R. Patil, S. B. Radder, S. J. Armaković and S. Armaković, J. Mol. Struct., 2019, 1178, 1-17. DOI:10.1016/j.molstruc.2018.10.007

67. C. A. Lipinski, F. Lombardo, B. W. Dominy and P. J. Feeney, Adv. Drug Deliv. Rev. 2001, 46, 3-26.

DOI:10.1016/S0169-409X(00)00129-0

68. C. A. Lipinski, Drug Discov. Today. Technol., 2004, 1, 337341. DOI:10.1016/j.ddtec.2004.11.007

69. A. Verma, Asian Pac. J. Trop. Biomed., 2012, 2, 1735-1737. DOI:10.1016/S2221-1691(12)60486-9

70. P. Ertl, B. Rohde and P. Selzer, J. Med. Chem., 2000, 43, 37143717. DOI:10.1021/jm000942e

Topal: Synthesis, Crystallographic Structure, Hirshfeld Surface ... 
71. S. Nadeem, M. Sirajuddin, S. Ahmad, S. A. Tirmizi, M. I. Ali and A. Hameed, Alexandria J. Med., 2016, 52, 279-288.

DOI:10.1016/j.ajme.2015.10.003

72. S. Deswal, Naveen, R. K. Tittal, D. Ghule Vikas, K. Lal and A. Kumar, J. Mol. Struct., 2020, 1209, 127982.

DOI:10.1016/j.molstruc.2020.127982
73. D. F. Veber, S. R. Johnson, H.-Y. Cheng, B. R. Smith, K. W. Ward and K. D. Kopple, J. Med. Chem., 2002, 45, 2615-2623. DOI:10.1021/jm020017n

74. N. Dege, A. S. Aydın, E. Ağar, S. Kansız, S. JoseKavitha, K. BalaSubramani, M. Hemamalini and V. Rajakannan, Chem. Data Collect., 2020, 25, 100320. DOI:10.1016/j.cdc.2019.100320

\section{Povzetek}

A detailed description of the two new pyridine ligands, (2E,3Z)-3-[2-(3-chloropyridin-2-yl)hydrazinylidene]-N-hydroxybutan-2-imine and 3-chloro-2-\{(2Z)-2-[1-(4 nitrophenyl)ethylidene]hydrazinyl $\}$, is reported. The synthesized compounds were characterized by spectroscopic studies, spectral features were performed by TD-DFT calculations. New-generation pyridine ligand of $\mathrm{HL}_{2}$ was also determinate by single-crystal X-ray diffraction and Hirshfeld surface analysis with two-dimensional fingerprint plots was used to analyze intermolecular interactions in crystals. Molecular-docking was performed to investigate the binding areas of chemical compounds, and the results showed the inhibitory activity of the studied $\mathrm{HL}_{1}$ and $\mathrm{HL}_{2}$ against $E$. coli. The results of the current study revealed the drug-likeness and bioactive properties of the ligands.

Podan je podroben opis dveh novih piridinskih ligandov, (2E,3Z)-3-[2-(3-kloropiridin-2-il) hidraziniliden]-N-hidroksibutan-2-imina in 3-kloro-2-\{(2Z)-2-[1-(4nitrofenil)etiliden] hidrazinila\}. Sintetizirane spojine so bile okarakterizirane s spektroskopskimi študijami, spektralne značilnosti pa so bile ovrednotene z izračuni TD-DFT. Nova generacija piridinskih ligandov HL2 je bila določena tudi z žarkovno rentgensko difrakcijo, za analizo medmolekularnih interakcij v kristalih pa je bila uporabljena Hirshfeldova površinska analiza s specifičnimi dvodimenzionalnimi prikazi. Za proučitev vezavnih površin kemijskih spojin smo izvedli molekularno sidranje, pri čemer so rezultati pokazali inhibitorno aktivnost proučevanih $\mathrm{HL}_{1}$ in $\mathrm{HL}_{2}$ spojin napram E. coli. Rezultati sedanje študije kažejo na potencialne zdravilne in bioaktivne lastnosti ligandov.

Except when otherwise noted, articles in this journal are published under the terms and conditions of the Creative Commons Attribution 4.0 International License 